\title{
Impact of non-fossil electricity on the carbon emissions embodied in China's exports
}

\author{
Rong Yuan a, b, *, João F.D. Rodrigues a , Paul Behrens a, c \\ a Institute of Environmental Sciences, CML, Leiden University, Einsteinweg 2, 2333 CC Leiden, The Netherlands \\ b School of Management and Economics, Tianjin University, Weijin 92, 300072 Tianjin, PR China \\ ${ }^{\mathrm{c}}$ Leiden University College The Hague, Leiden University, Anna van Buerenplein 301, 2595 DG The Hague, The Netherlands
}

\section{A R T I C L E I N F O}

\section{Article history:}

Received 7 August 2017

Received in revised form

20 March 2018

Accepted 28 April 2018

Available online 30 April 2018

\section{Keywords:}

$\mathrm{CO}_{2}$ emissions

Non-fossil electricity

Multi-regional input-output model

Electricity transmission

Supply-chain effect

\begin{abstract}
A B S T R A C T
Embodied carbon emissions have been particularly high in Chinese exports due to the domination of coal consumption in China's electricity mix. In order to decarbonize China's electricity system, the government of China embarked on a large-scale, national roll-out of non-fossil electricity (NE). Thus, understanding the carbon impacts of NE may help facilitate China's efforts to reduce emissions embodied in exports. This study builds a hybrid, energy-economic, multi-regional input-output (MRIO) model to investigate the impact of NE development on emissions embodied in exports by comparing the observed NE expansion against a counterfactual scenario without NE deployment. The total contribution of NE expansion between 2002 and 2014 is decomposed into three factors: intraregional, electricity transmission as well as inter-regional supply-chain. Our results show that NE expansion reduced carbon emissions embodied in exports by $203 \mathrm{Mt}$ (million tonnes) in 2007, $243 \mathrm{Mt}$ in 2010 and $259 \mathrm{Mt}$ in 2014. These mitigated emissions accounted for $11.3 \%$ in $2007,14.9 \%$ in 2010 and $19.5 \%$ in 2014 of the total emissions embodied in exports. The intra-regional effect accounted for approximately $60 \%$ of those $\mathrm{CO}_{2}$ savings during 2007-2014. The effect of electricity transmission accounted for more than $20 \%$, and the remainder of emission reductions resulted from inter-regional economic linkages.
\end{abstract}

(c) 2018 Published by Elsevier Ltd.

\section{Introduction}

China has witnessed a sustained growth of exports in the last two decades, with an annual average growth rate of $6 \%$ between 1995 and 2014 (Liu et al., 2016b). China saw a significant expansion in exports after entering the World Trade Organization in 2001, growing at more than 20\% per annum from 2001 to 2012 (NBS, 2013). In 2015, China became the world's largest exporter (The World Bank, 2013) and accounted for a share of $13.8 \%$ of global trade, whereas that share was less than $2 \%$ in 1990 (World Trade Organization, 2016). Such large changes in the size of China's exports from 2002 to 2014 also led to large changes in the carbon emissions induced by exports, that is the total export-embodied emissions. Previous studies on embodied emissions have showed that over the last few decades nearly a quarter of $\mathrm{CO}_{2}$ emissions in

\footnotetext{
* Corresponding author. Institute of Environmental Sciences, CML, Leiden University, Einsteinweg 2, 2333 CC Leiden, The Netherlands.

E-mail address: r.yuan@cml.leidenuniv.nl (R. Yuan).
}

China were related to the production of traded goods and services (Peters et al., 2011).

In 2004, the embodied emissions that derived from China and were exported to Japan, the United States, and Russia represented $48 \%, 44 \%, 42 \%$ of their total import-embodied emissions, respectively (Liu, 2015). Concurrently, developed countries witnessed the decrease or stabilization of domestic carbon emissions (Lin et al., 2014). However, these decreases were compensated by increased emissions embodied in imports from other nations, and from China in particular (Davis et al., 2011). In 2007, the Chinese trade yielded a net export of $2 \mathrm{Gt}$ of $\mathrm{CO}_{2}$-eq, with $1.6 \mathrm{Gt} \mathrm{CO}_{2}$-eq going to Europe, and a net-export of over $1 \mathrm{Gt} \mathrm{CO}_{2}$-eq to the United States (Tukker et al., 2014). China represented the largest exporter to the Mediterranean area, with $197 \mathrm{Mt}$ export-embodied $\mathrm{CO}_{2}$ emissions in 2012 (Caro et al., 2017).

However, recent data shows that the total emissions in China, for the first time in recent history, were lower in 2015 than the year before (EDGAR, 2016). This recent decline is likely explained by the development of non-fossil electricity (NE), as China has become one of the world's leaders in NE generation (Wu et al., 2016a). The 


\begin{tabular}{|c|c|c|c|}
\hline \multicolumn{2}{|c|}{ Nomenclature } & $\mathrm{y}$ & Column-vector of exports \\
\hline NE & Non-fossil electricity & $\mathrm{E}$ & Electricity intensity matrix \\
\hline Mt & Million tonnes & $\mathrm{T}$ & Inter-regional electricity transmission matrix \\
\hline MRIO & Multi-Regional Input-Output & $\mathrm{S}$ & Energy structure matrix \\
\hline IO & Input-Output & $\mathrm{F}$ & Carbon emission coefficient matrix \\
\hline CGE & Computable general equilibrium & $\mathrm{u}$ & Column-vector of electricity demand \\
\hline SDA & Structural ecomposition analysis & $\mathrm{C}_{\mathrm{tar}}$ & Carbon emissions in the target year \\
\hline HEM & Hypothetical extraction method & $\mathrm{C}_{\mathrm{ref}}$ & Carbon emissions in the reference year \\
\hline GLMDI & Generalized logarithmic mean Divisia index & $\mathrm{C}_{\mathrm{alt}}$ & Carbon emissions in the counterfactual scenario \\
\hline EpV & $\mathrm{CO}_{2}$ emissions per value added & $\Delta \mathrm{C}_{\text {tot }}$ & Net carbon impacts of non-fossil electricity \\
\hline LMDI & Logarithmic mean Divisia index & & development \\
\hline IDA & Index decomposition analysis & $\Delta \mathrm{C}_{\text {self }}$ & Intra-regional effect of non-fossil electricity \\
\hline ENA & Ecological Network Analysis & & development \\
\hline CESY & China Energy Statistical Yearbooks & $\Delta \mathrm{C}_{\text {trans }}$ & Electricity transmission effect of non-fossil electricity \\
\hline CEPY & China Electric Power Yearbook & & development \\
\hline A & Technical coefficient matrix & $\Delta \mathrm{C}_{\text {supp }}$ & Supply-chain effect of non-fossil electricity \\
\hline B & Environmental interventions matrix & & development \\
\hline I & Identity matrix & & \\
\hline
\end{tabular}

generation of NE increased almost fivefold from 288 TWh in 2002 to 1375 TWh in 2014, as shown in Fig. 1. Up until 2006, NE generation increased modestly on a yearly basis, and thereafter it accelerated. This may be attributed to the 2006 Renewable Energy Law (Hua et al., 2016). By 2014, 24.5\% of total electricity generation was from NE, compared to $16.7 \%$ in 2006 . Hydropower dominated the growth, accounting for $15.9 \%$ of the total electricity generation in 2002 , and $18.9 \%$ by 2014 . Wind power generation grew approximately 700\% per annum between 2006 and 2014. Solar power generation also increased quickly in recent years after the implementation of the 2011 national feed-in tariff (Wang et al., 2016). After four years of rapid growth at an annual growth rate of over $300 \%$, solar power generation reached 23 TWh by 2014 , accounting for $0.4 \%$ of the total electricity generation. NE development will likely have significant impacts on the carbon emissions embodied in exports. In particular, they may influence the amount of carbon leakage (Weber et al., 2008). In spite of the clear policy relevance, surprisingly little effort has been paid to the analysis of the historical impact of NE development on China's exportembodied $\mathrm{CO}_{2}$ emissions. The present paper addresses this knowledge gap.

China is not only a large country, but also regionally diverse. The majority of international exports originate in the eastern, coastal provinces with Shanghai, Jiangsu, Zhejiang, Shandong, and Guangdong, accounting for $74 \%$ of China's exports during the period 2002-2014 (NBS, 2015b). At the same time, China

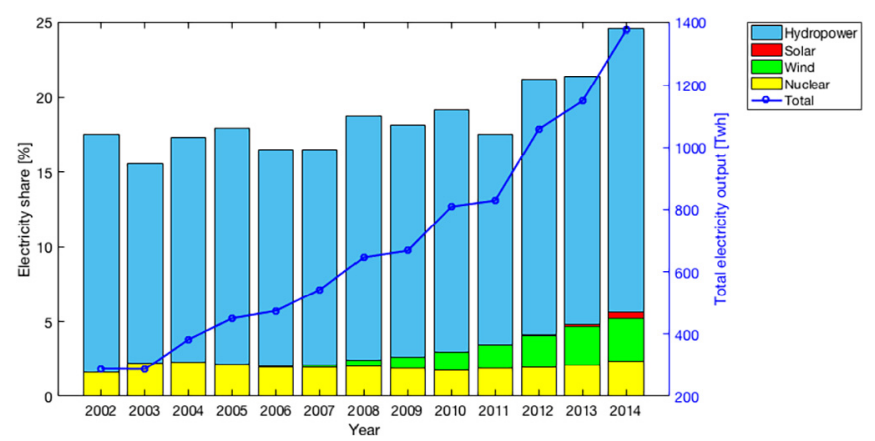

Fig. 1. Evolution of shares of different NE types for electricity generation in China (2002-2014). demonstrates significant spatial heterogeneity in NE expansion (see Fig. 2). In 2002, the southwestern provinces, Qinghai, Sichuan, Yunnan, and Guangxi saw the highest penetration of NE, accounting for over $50 \%$ of the total electricity generation. NE generation in the southwestern region also experienced an increase between 2002 and 2014. For example, the share of NE generation in Yunnan

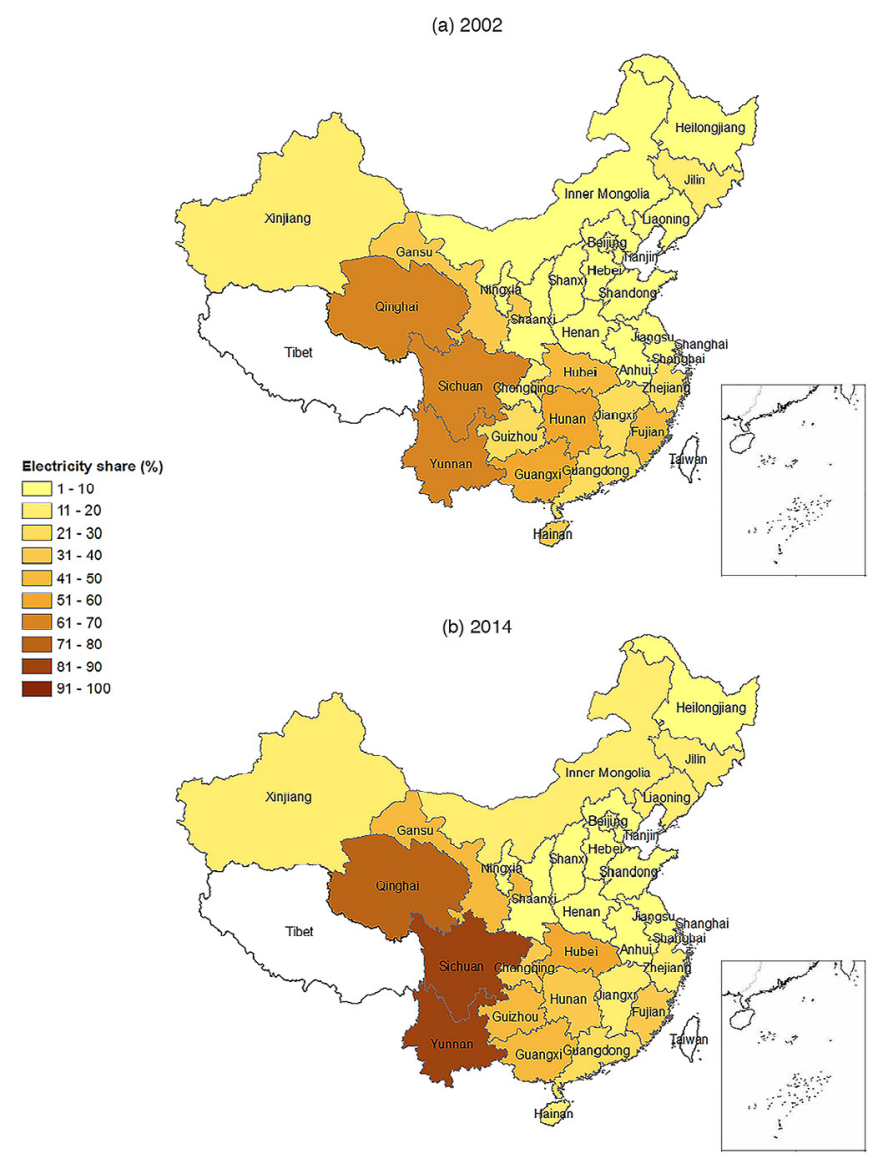

Fig. 2. Share of NE in total electricity generation for different provinces (2002 and 2014). 
increased to 84.3\% in 2014 from 61.4\% in 2002. In 2014, Qinghai, Hubei, Sichuan, Yunnan, and Guangxi ranked in the top five in terms of the share of NE generation. NE generation in the northern region also experienced a significant growth between 2002 and 2014. For example, the share of NE generation in Inner Mongolia increased from $1.6 \%$ to $11.6 \%$ with an annual growth rate of $6 \%$. These heterogeneities in both the amount of exports and the endowment of $\mathrm{NE}$ resources mean that, in order to assess the impact of NE expansion on China's export-embodied emissions, a spatially-explicit analysis is necessary.

The fundamental question this study wishes to answer is whether the large-scale development of NE during the period 2002-2014 led to a significant reduction of emissions embodied in China's exports. A natural follow-up question is to identify which mechanism is responsible for this behavior. Given the existence of both spatial heterogeneity and economic linkages, this study uses a multi-regional input-output (MRIO)-based model to consider three distinct mechanisms: expansion of the share of NE in intra-regional electricity generation; electricity transmission between provinces, allowing for NE to be used in different provinces; and supply-chain effect, whereby international exports in a province is assembled from intermediate inputs produced in other regions. This means that the carbon impacts of non-fossil electricity development can be analyzed in region A by decomposing them into three effects: 1 ) development of NE generation within region A itself; 2) development of NE generation in other regions, which region $A$ then imports as electricity; and, 3 ) changes in the supply chain when region A purchases parts from other regions to produce goods. This study addresses these questions by comparing the historical carbon emissions embodied in Chinese exports against a counterfactual in which the NE expansion of 2002-2014 did not take place, and the corresponding electricity load is instead generated from fossil fuels. A methodological question that this study has to address is that the most recent, official Chinese MRIO table is from 2010, but large changes in NE generation were observed between 2010 and 2014. As this is an important period, a projected MRIO table for 2014 is built.

In summary, this paper is novel in three key ways. Firstly, this study presents the first-ever analysis of the impact of NE expansion on China's export-embodied carbon emissions, thus clarifying the contribution of China's energy policy to the carbon leakage in international trade. Secondly, this analysis is performed neither for a single year nor for China as a whole, but performed for every province and for several years. This level of detail is important given the dynamic nature of China's economic development, the heterogeneity of China's regions, as well as inter-regional economic and electricity interconnections. Finally, there is a theoretical contribution in this paper to the extent that this study develops a multi-regional economic-energy hybrid model and scenario analysis framework in which the decomposition above could be performed. This model describes the electricity sector in physical terms, thus improving the quality of data.

The rest of the paper is organized as follows: Section 2 summarizes the literature; Section 3 introduces the methods; Section 4 describes the data sources; the results are presented in Section 5; Section 6 presents the conclusions and policy implications.

\section{Literature review}

\subsection{Analysis of environmental impacts of non-fossil fuel electricity development}

This study builds upon recent research focusing on the link between NE expansion and the environment. There are several different methods available to evaluate environmental impacts of
NE development, including bottom-up energy system models ( $\mathrm{Li}$ et al., 2012; Budzinske et al., 2017), and top-down energy-economy models (Sonnenschein and Mundaca, 2016). Hybrid approaches combining these methods have also been used (Wolfram et al., 2016). Bottom-up modeling focuses on the energy sector alone, but cannot resolve economic impacts and does not include inter-sectorial/regional feedback effects (Horschig and Thrän, 2017). Top-down modeling focuses on the interaction between the energy sector and the whole economy, and can be used to quantify the impact of energy transition on the rest of the economy (Qi et al., 2014b; Dai et al., 2016). Among top-down approaches, IO models consider the economy as a whole, and are particularly suitable for modeling short-term effects associated with energy technologies (Yushchenko and Patel, 2016). Some IO analyses focus on the environmental impacts associated with future electricity generation technologies (Hienuki et al., 2015). For example, Song et al. (2015a, b) use IO models and scenario analyses to evaluate the environmental impact arising from future electricity mix in China. Kumar et al. (2016) employ IO models to assess the carbon impact of wind energy farms in the United States. Nagashima et al. (2017) apply IO models to analyze the environmental impact of wind power development in Japan. Fang et al. (2017) used IO models to explore the environmental impact of the exploitation of renewable resources on the low-carbon industrial park. However, most studies assess the gross environmental impact of NE development at the national/regional level, and few studies evaluate the impacts of NE expansion on carbon emissions embodied in China's exports.

\subsection{IO analysis and China's export-embodied carbon emissions}

Given China's dual importance as one of the world's largest $\mathrm{CO}_{2}$ emitters, and the global leader in trade, IO-based studies on $\mathrm{CO}_{2}$ emissions embodied in China's trade have been conducted (Qi et al., 2014a; Liu et al., 2016a; Tang et al., 2017; Zhao et al., 2017b). Some researchers use single-region IO models to assess the trend of China's export-embodied emissions, and estimate the drivers of changes in embodied emissions (Weber et al., 2008, Xu et al., 2011; Liu et al., 2017; Tian and Lin., 2017). However, the single-region IO model does not present complex multiple foreign trade links (Vetné Mózner, 2013; Xu et al., 2017), and multiregional approaches have been introduced to calculate export-embodied emissions from the perspective of global supply chains (Peters et al., 2011; Deng et al., 2016; Andersson, 2018). Some studies focus on the $\mathrm{CO}_{2}$ emissions embodied in international trade with specific trading countries, such as the US (Zhao et al., 2016, 2017a), Japan (Wu et al., 2016b), UK (Li and Hewitt, 2008), and others. These studies show that China is a net exporter of $\mathrm{CO}_{2}$ emissions embodied in trade with developed countries.

However, given discrepancies in the levels of economic development between provinces in China, the analysis of embodied $\mathrm{CO}_{2}$ emissions at the national level does not reflect the characteristics of individual regions very well. Also, since emission studies at the national level neglect feedback and spillover effects between regions, the results should be considered approximations ( $\mathrm{Su}$ and Ang, 2010). Given this, there has been work to use China's MRIO tables in exploring the impact of inter-regional transfer of emissions on China's export-embodied emissions (Feng, 2012; Guo et al., 2012; Meng et al., 2013; Weitzela and Ma, 2014; Jiang et al., 2015; Liu et al., 2015a; Tang el al., 2015; Wang et al., 2015; Duan et al., 2018). These studies show that the carbon flows from the central and western regions to the eastern region are the largest contributors to China's export-embodied emissions. Others quantify the driving factors of changes in export-embodied emissions at the regional level in China using decomposition approaches (Zhang 
and Tang, 2015; Liu et al., 2015b; Mi et al., 2017), and find that lowcarbon energy infrastructure may reduce embodied $\mathrm{CO}_{2}$ emissions. A comparison of results of IO-based studies of China's exportembodied emissions is shown in Table A.1 of Appendix. Note, however, no IO model (or a similar approach) has examined the impact of historical NE development on China's export-embodied emissions with sub-national regional details.

\section{Methods}

The starting point for this analysis is an environmentallyextended MRIO model (Miller and Blair, 2009), which allows for the calculation of environmental impacts of a demand stimulus in an exporting region (that is, a region's emissions embodied in exports) as:

$\mathrm{C}=\mathrm{B}(\mathrm{I}-\mathrm{A})^{-1} \mathrm{y}$

Let $n_{R}$ be the number of regions, $n_{S}$ be the number of industries and $n_{F}$ be the number of fuel types. $\mathbf{Y}$ is a column-vector of exports of length $n_{R} n_{S}$, with nonzero values in the entries of the exporting region and empty for the remaining values; $\mathbf{A}$ is a square technical coefficient matrix with side of length $n_{R} n_{S}$, expressing how many inputs from other sectors a given sector requires to generate a unit of output; I is an identity matrix; B is a matrix of environmental interventions, with $n_{R}$ rows and $n_{R} n_{S}$ columns, expressing carbon emissions in the electricity-generating region (in rows) per unit of economic output of the exporting region and sector (in columns); and $\mathbf{C}$ is a resulting column-vector of regional emissions of length $n_{R}$. This study specifies Eq. (1) directly in terms of a target exporting region to simplify the notation, the analysis can then be performed iteratively for all regions.

In order to study how a change in one region's electricity generation structure will impact the carbon intensity of an exporting industry of that region or a different region, the matrix of environmental interventions is decomposed as:

$\mathrm{B}=\mathrm{FS} \mathrm{T} \mathrm{E}$

In the expression above, $\mathbf{E}$ is a matrix with $n_{R}$ rows and $n_{R} n_{S}$ columns which shows how much electricity (in kWh) is consumed in each region to generate the total economic output of each industry (in yuan) in that same region; $\mathbf{T}$ is a matrix of inter-regional electricity transmission (Zhang et al., 2017), with $2 n_{R}$ rows (to distinguish between production for domestic use and for interregional transmission) and $n_{R}$ columns, which shows how much electricity is generated in a given region to satisfy consumption in another (and itself); $\mathbf{S}$ is an energy structure matrix, with $2 n_{R}$ columns and $2 n_{R} n_{F}$ rows, reflecting the use of different energy sources (coal, hydro, solar, etc) in the total electricity generation in each region (the factor of 2 in the number of rows and columns is required to distinguish between electricity production for intraregional consumption and for inter-regional transmission); $\mathbf{F}$ is a carbon emission coefficient matrix with $2 n_{R}$ rows and $2 n_{R} n_{F}$ columns, which expresses the carbon emissions $\left(\mathrm{MtCO}_{2}\right)$ per electricity generated $(\mathrm{kWh})$ of different energy sources (coal, hydro, solar, etc); finally, B in Eq. (1) is substituted by a matrix with $2 n_{R}$ rows and $n_{R} n_{S}$ columns, which distinguishes between carbon emissions per unit of economic output for domestic use and for inter-regional transmission. Note that since the electricity sector is described separately from the rest of the economy, the rows and columns of matrix A corresponding to the electricity sector need to be set to zero to avoid double counting (Stromman et al., 2009).

The model described above is an energy-economic sequential hybrid model (Guevara and Rodrigues, 2016) based on the parallel models of Bullard and Herendeen (1975) or Joshi (1999), in which the energy use to generate electricity is described in physical units as separate matrices, and the rest of the economy is described in monetary units. The term hybrid denotes a combination of physical and monetary units. Hybrid analyses are useful, as the actual energy use data of the electricity sector can be inserted in the MRIO model in physical units, such that the MRIO model's reliability can be improved (Tian and Lin, 2017). Specifically, the main advantage of this formulation is that it becomes possible to use (non-monetary) energy data to describe electricity generation and interregional electricity transmission, which will become apparent when addressing the issue of data availability in the following section and scenario construction further below in this section. This provides more detailed information and is more rigorous than the alternative monetary data. A drawback of our approach is that lifecycle or upstream indirect impacts of electricity use (the emissions associated with the transport of energy or supporting services such as insurance) are not accounted for. However, closing this loop (making the system parallel) would require substantial effort in collecting data to disaggregate the use of non-energy inputs of the electricity sector (a single-sector in the economic matrix) into several electricity generation technologies. Note also that the goal of the present study is not to study impacts of electricity generation but impacts of changes in energy structure on all emissions resulting from electricity generated along the supply chain of those exports.

This study is not only interested in calculating the impact of an isolated demand stimulus but, following the approach of Behrens et al. (2016), this study compares the impact of NE expansion between a reference year and a target year against a counterfactual scenario in which NE generation did not take place and is the same as in a reference year. In the counterfactual, the difference in electricity generation is provided by the most likely fossil fuel source, which in the case of China is coal. There are two separate aspects to consider. The first is to quantify the impact from the additional generation capacity beyond the one available in the reference year, as non-fossil fuel capacity that already existed would not have been removed. The second is the comparison of the two scenarios. It is convenient to define the column-vector of electricity demand, $\mathbf{u}$, of length $2 n_{R}$ as:

$\mathrm{u}=\mathrm{TE}(\mathrm{I}-\mathrm{A})^{-1} y$

such that the carbon emissions from a demand stimulus simplify to F S u. The aim of simplification is to isolate the terms that will vary in the construction of scenarios. All terms in the right-hand side of Eq. (3) will change together, and can be compressed to a single variable.

This study focuses on the $\mathrm{CO}_{2}$ impact of $\mathrm{NE}$ expansion and therefore restricts attention to the impact on $\mathrm{CO}_{2}$ emissions of increased electricity output beyond that of the reference year. This is based on the assumption that no installation is expected to be decommissioned and the electricity generation that is present in the reference year will continue to generate over the time-span considered. This implies that the carbon emissions in the target year are split between embodied emissions from electricity generation by technologies already installed in the reference year, and embodied emissions from the increased capacity installed between the reference and target years:

$\mathrm{C}_{\mathrm{tar}}=\mathrm{FS}_{\mathrm{ref}} \mathrm{u}_{\mathrm{ref}}+\mathrm{F} \mathrm{S}_{\mathrm{tar}}\left(\mathrm{u}_{\mathrm{tar}}-\mathrm{u}_{\mathrm{ref}}\right)$

In the expression above, subscript 'tar' describes what happens in the target year, and 'ref' describes what happens in the reference year. There are two terms on the right-hand side of Eq. (4): the first represents the emissions from the technology that remains from 
the reference year; the second represents the additional emissions from the technology installed between the reference and target years. Note that term $\mathbf{F}$ lacks a subscript since the emission coefficients per unit of electricity generated for each technology do not change over the time span of the study.

The impact of the counterfactual can use a similar expression as:

$\mathrm{C}_{\mathrm{alt}}=\mathrm{FS}_{\mathrm{ref}} \mathrm{u}_{\mathrm{ref}}+\mathrm{FS}_{\mathrm{alt}}\left(\mathrm{u}_{\mathrm{tar}}-\mathrm{u}_{\mathrm{ref}}\right)$

The subscript 'alt' describes the counterfactual scenario in which the observed NE expansion is replaced by coal. Note that the only change between Eqs. (4) and (5) is the energy structure. Both the technology-specific emission coefficients and the electricity demand are identical in both scenarios. This study therefore assumes that additional fossil-fuel capacity installed in the counterfactual scenario takes place in the region in which the NE generation in the target scenario is being replaced. Eqs. (4) and (5) can now be combined to obtain the net impact of NE expansion, 'tot', as:

$\Delta \mathrm{C}_{\text {tot }}=\mathrm{C}_{\mathrm{tar}}-\mathrm{C}_{\mathrm{alt}}=\mathrm{F}\left(\mathrm{S}_{\mathrm{tar}}-\mathrm{S}_{\mathrm{alt}}\right)\left(\mathrm{u}_{\mathrm{tar}}-\mathrm{u}_{\mathrm{ref}}\right)$

This study is also interested in decomposing $\Delta \mathbf{C}_{\text {tot }}$ into three components: intra-regional effect (the expansion of $\mathrm{NE}$ in the exporting region, $\boldsymbol{\Delta} \mathbf{C}_{\text {self }}$ ), inter-regional electricity transmission effect ( $\left.\Delta \mathbf{C}_{\text {trans }}\right)$, and supply-chain effect $\left(\Delta \mathbf{C}_{\mathbf{u p}}\right)$. The total effect is therefore obtained by partitioning as:

$\Delta \mathrm{C}_{\text {tot }}=\Delta \mathrm{Cs}_{\text {elf }}+\Delta \mathrm{C}_{\text {trans }}+\Delta \mathrm{C}_{\text {supp }}$

$\Delta \mathrm{C}_{\text {self }}=\mathrm{C}_{\mathrm{tar}}-\mathrm{C}_{\text {self }}=\mathrm{F}\left(\mathrm{S}_{\mathrm{tar}}-\mathrm{S}_{\text {self }}\right)\left(\mathrm{u}_{\mathrm{tar}}-\mathrm{u}_{\mathrm{ref}}\right)$

$\Delta \mathrm{C}_{\text {trans }}=\mathrm{C}_{\text {self }}-\mathrm{C}_{\text {trans }}=\mathrm{F}\left(\mathrm{S}_{\text {self }}-\mathrm{S}_{\text {trans }}\right)\left(\mathrm{u}_{\text {tar }}-\mathrm{u}_{\text {ref }}\right)$

$\Delta \mathrm{C}_{\mathrm{up}}=\mathrm{C}_{\text {trans }}-\mathrm{C}_{\mathrm{alt}}=\mathrm{F}\left(\mathrm{S}_{\text {trans }}-\mathrm{S}_{\mathrm{alt}}\right)\left(\mathrm{u}_{\mathrm{tar}}-\mathrm{u}_{\mathrm{ref}}\right)$

In the previous expressions $\boldsymbol{S}_{\mathbf{t a r}}$ and $\boldsymbol{S}_{\text {alt }}$ are, respectively, the energy structure in the target year in all regions, and the counterfactual energy structure in which all NE is replaced by coal. $\mathbf{S}_{\text {self }}$ and $S_{\text {trans }}$ have some values that are identical to the energy structure in the target year and others that are identical to the counterfactual scenario, as explained below.

The first effect reflects the expansion of NE in the exporting region alone. Thus, $\mathbf{S}_{\text {self }}$ uses the counterfactual energy structure in the block for the domestic production of the exporting region and the historically observed energy structure in all other blocks. Therefore, in the counterfactual scenario, NE expansion for intraregion electricity generation did not occur in the exporting region, but did in all other regions, and even in the domestic production for intermediate inputs that export to other provinces. The two other effects are related to NE development occurring in other regions but propagating through different causal links: electricity transmission and supply-chain effects. To be able to split these two effects, this study does not use SDA as a method, but uses the network approach of Rodrigues et al. (2016) to distinguish electricity generated for export to the exporting region, from the total electricity generation. Formally, this is achieved by explicitly considering two electricity sectors per region, both with the same emission coefficients, but one satisfying the demand of exporting region and the other satisfying the demand of all other regions. Then, regarding $\mathbf{S}_{\text {trans, }}$ the domestic electricity generation of exporting region uses the target energy structure and all other regions transmitting to the exporting region use the counterfactual energy structure.
This means that $\mathbf{C}_{\text {trans }}$ reflects the sum of intra-regional NE expansion and inter-regional electricity transmission effects, and $\mathbf{C}_{\text {alt }}$ reflects the sum of all effects. That is why each individual effect in Eqs. 7(2)-7(4) are expressed as the difference between sequential gross impacts, e.g., the impact of intra-regional $\mathrm{NE}$ expansion, $\mathbf{\Delta} \mathbf{C}_{\text {self }}$, is the difference between $\mathbf{C}_{\text {alt }}$ and $\mathbf{C}_{\text {trans. }}$

\section{Data}

Fossil fuel and electricity consumption data are obtained from the Comprehensive Energy Balance Table for each province in the China Energy Statistical Yearbooks (CESY) (NBS, 2003, 2008, 2011, 2015a). Data for generation in all 30 regions are derived from the China Electric Power Yearbook (CEPY) (CEPYEB, 2003, 2008, 2011, 2015). This dataset includes five electricity generation types (thermal power, nuclear, hydropower, wind, solar). Since sufficient data on the amount of thermal power generated from different fossil fuel types is lacking (e.g. thermal power generated from coal consumption), this study uses the net coal consumption rate for fossil-fired power plants (gce/kwh) in the CESY (NBS, 2003, 2008; 2011, 2015a) to convert physical coal to electricity generated. The main data source for fossil fuel consumption embodied in the transformation of thermal power are also from the CESY (NBS, 2003, 2008, 2011, 2015a). We set the carbon emission coefficients of nonfossil electricity sources as zero. Electricity transmission data for provincial grids in 2007, 2010, and 2014 are from the Annual Report of Power Market Transactions (SGC, 2008, 2011, 2015). Electricity transmission data for provincial grids in 2002 are from the CEPY (CEPYEB, 2003). China's electricity transmission data are split between province-to-province transmission in six sub-national power grids and province-to-sub-national-grid transmission. This study uses Zhang et al. (2017)'s methods and assumptions to disaggregate province-to-sub-national grid transmission according to the spatial connection of transmission lines between the delivering side and receiving side. Data for transmission losses from the literature are used (CEPYEB, 2003, 2008; 2011, 2015; Kosuke K, 2003; Chen et al., 2014; Zhang et al., 2017).

This study utilizes MRIO tables of China's 30 provinces for 2002, 2007 and 2010 (Shi and Zhang, 2012; Liu et al., 2012, 2014). For lack of data, Tibet, Hong Kong, Macau and Taiwan have been excluded from China's MRIO tables. This study aggregates the 30 sectors in 2007 and 2010 tables to 21 sectors to match the 2002 table (see Table A.2 of Appendix). Large changes in NE were witnessed between 2010 and 2014 (as shown in Fig. 1). Since official MRIO tables are available only to 2010, this study builds a projection for 2014 . Ideally, this study would establish a new MRIO dataset for 2014 by implementing a survey on a large enough scale. But since establishing new MRIO datasets is time-consuming and costly, the RAS method (Lahr and de Mesnard, 2004) (a particular bi-proportional matrix balancing method (Rodrigues, 2014)) is utilized to update the MRIO table for 2014 in a similar way as performed by Lee et al. (2011), Cai et al. (2014), Chun et al. (2014) and Varela-Vázquez and Sánchez-Carreira (2015). This is described below.

First, this study computes the sum of rows and columns of the intermediate flow matrix for 2014 based on the 2014 data for output level, final demand, trade, and value added. This study then obtains the 2014 data for final demand and value added per region from NBS (2015b). Due to the lack of data for sectoral output in 30 provinces, this study considers economic growth rates of five major sectors (agriculture, industry, construction, transportation, and services) per province during the period 2010-2014, and uses a proportional adjustment approach to estimate sectoral outputs per province in 2014. Moreover, in order to quantify the changes in trade structure, this study uses the trade flows by sector in each region collected by Chinese Customs to build import and export 
vectors for 2014. Then, using the RAS method, the technical coefficient matrix (A) can be updated from a knowledge of the intermediate flow matrix in the base year (2010), and the row and column totals of the flow intermediate matrix for 2014. The updated technical coefficient matrix reflects the changes in interdependencies between different sectors in China's economy during the period 2010-2014. Finally, the column-vector of export for 2014 is exogenously specified.

Since this study includes recorded data of economic output, final demand and international trade in 2014, and given the small timeframe considered, it expects that 2010 offers a good starting point for the application of the RAS method in projecting the economic structure of 2014. Note that by using a hybrid energyeconomic model as described in Section 3, it is possible to use a physical description of inter-regional electricity transmission which is already available for the year 2014, so the RAS estimation is only performed for non-electricity sectors. Given the importance of electricity transmission to the subject of this study, potential uncertainties due to the introduction of the MRIO table for 2014 is greatly reduced. In order to apply the method described in Section 3 , this study needs to specify a reference year. This study considers the reference year to be 2002 , as it precedes the NE expansion as shown in Fig. 1.

\section{Results}

First, this study describes the impact of NE development on emissions embodied in exports over time, and reports the differences observed at the regional level. Then, this study presents the contribution of electricity transmission to emissions embodied in exports. Finally, this study evaluates the impact of NE on interregional $\mathrm{CO}_{2}$ transfers.

\section{1. $\mathrm{CO}_{2}$ emissions embodied in provincial exports}

Table 1 shows the $\mathrm{CO}_{2}$ emissions embodied in provincial exports. China's $\mathrm{CO}_{2}$ emissions embodied in exports were $583 \mathrm{Mt}$ in 2002, $1801 \mathrm{Mt}$ in 2007, $1632 \mathrm{Mt}$ in 2010, and $1331 \mathrm{Mt}$ in 2014, respectively. The national results are similar to previous work (Guo et al., 2012 with $688.15 \mathrm{Mt}$ in 2002; Weitzela and Ma, 2014 with $1730 \mathrm{Mt}$ in 2007; Zhang et al., 2015 with $2108 \mathrm{Mt}$ in 2007, and $1616 \mathrm{Mt}$ in 2010), which indicates that the proposed $\mathrm{CO}_{2}$ emission accounting framework is reliable, and can be used for investigating the impact of $\mathrm{NE}$ development on embodied $\mathrm{CO}_{2}$ emissions. Between 2002 and 2007, $\mathrm{CO}_{2}$ emissions embodied in exports doubled. During the period 2007-2014, export-embodied carbon emissions decreased at an average annual rate of $3.7 \%$. The distribution of emissions embodied in exports followed the distribution of China's exports at the provincial level. Between 2002 and 2010, exportembodied emissions were the highest in the eastern region with Guangdong as the largest, accounting for $22.8 \%$ of the total in 2002 , increasing to $29.7 \%$ in 2014 . The next most important provinces were Jiangsu, Zhejiang, and Shandong, with shares above $10 \%$.

\subsection{Total impact of non-fossil electricity development}

Fig. 3 presents the total impact of NE expansion on exportembodied carbon emissions over the period through the three propagation effects (intra-regional, electricity transmission, and supply-chain). NE generation resulted in a mitigation of $203 \mathrm{Mt}$, $244 \mathrm{Mt}$, and $259 \mathrm{Mt}$ in 2007, 2010, and 2014 respectively. As a percentage of the total emissions embodied in exports, NE development resulted in a $\mathrm{CO}_{2}$ reduction of $11.3 \%$ in $2007,14.9 \%$ in 2010 and $19.5 \%$ in 2014 , respectively. There was a significant impact during 2010-2014 due to the large growth of NE from 2010 onwards. The intra-regional effect comprised about $60 \%$ of the total $\mathrm{NE}$ impact during the whole period. Electricity transmission had a major role in $\mathrm{CO}_{2}$ savings, resulting in a reduction of $50 \mathrm{Mt}, 53 \mathrm{Mt}$, and $62 \mathrm{Mt}$ in 2007, 2010 and 2014 respectively. Emission reductions as a percentage of the total export-embodied carbon emissions were $2.8 \%$ in $2007,3.2 \%$ in 2010 , and $4.6 \%$ in 2014 . Additionally, with the expansion of grid interconnections across China in the future ( $\mathrm{Li}$ et al., 2016), this phenomenon is likely to intensify, suggesting that the interests of China and high-income nations in climate negotiations will be further aligned. The supply-chain effect was also significant, resulting in a reduction of $41 \mathrm{Mt}$ in 2010, dropping to a net saving of $39 \mathrm{Mt}$ in 2014. These results indicate that the ongoing transition of China toward NE has contributed substantially to reducing carbon leakage in international trade.

\subsection{Spatial distribution of the impact of non-fossil electricity}

Given the substantial differences in NE development among provinces, it is important to investigate the spatial distribution of NE impacts through the three propagation effects across provinces and over the years. Fig. 4 shows the largest impact in 12 provinces over the period 2007-2014. The impact of NE development generally followed the provincial distribution of export-embodied emissions. As the most important trade provinces in China, Jiangsu, Zhejiang, and Guangdong had the largest carbon emission reductions. The intra-regional effect had a major role in $\mathrm{CO}_{2}$ savings in these provinces, contributing to more than $50 \%$ of the total NE impact. Most provinces were influenced heavily by the intraregional effect. Hebei and Shandong had a relatively smaller impact of NE than Sichuan and Hubei, even though their exportembodied emissions were larger. The provinces with abundant NE resources saw the largest intra-regional effect, such as Hubei, Sichuan, Yunnan, and Guangxi.

In some provinces, the effect of electricity transmission was responsible for very large emission savings. This implies that the impact of NE might be underestimated if only the generation side is considered. For example, Shanghai showed a mitigation of more than 5 Mt reduction from 2007 to 2014, with electricity transmission playing an important role due to the import of hydropower from the western region to the eastern region. From 2007 to 2014, mitigated emissions due to electricity transmission comprised over $48 \%$ of the total NE impact in Shanghai. Also, electricity transmission was an important driver for the reduction of $\mathrm{CO}_{2}$ emissions in Hebei. Earlier, in 2007, electricity transmission yielded relatively small reductions in $\mathrm{CO}_{2}$ emissions in Hebei due to cheap, coal-fired electricity imported from adjacent provinces. While Hebei's neighboring provinces (e.g. Inner Mongolia and Shanxi) did expand NE generation over the period, the effect of electricity transmission comprised $40.1 \%$ of the total impact, resulting in a reduction of $2.39 \mathrm{Mt}$ in 2014. Clearly, whether electricity transmission impacts emission mitigation depends on the level of NE development in neighboring provinces. This is because NE expansion in neighboring provinces will reduce the imports of coal-fired electricity.

Another factor influencing the impact of NE expansion in Shanghai and Hebei was from supply chains. In 2014, Shanghai's supply-chain effect resulted in a reduction of $3.26 \mathrm{Mt}$, comprising $49 \%$ of the total impact. Shanghai is the economic center of the eastern region but has very limited energy resources, thus, its demand for exports stimulates the production of upstream industries (e.g. electricity sector) in the central and western regions (Zhong et al., 2017). Since the central and western regions provide a large quantity of intermediate products to Shanghai, NE development in these regions reduce Shanghai's export-embodied emissions. In 2007, the supply-chain effect was the most important factor underling Hebei's large NE impact, accounting for $53 \%$ of the total NE 
Table 1

Provincial carbon emissions embodied in exports $\left(\mathrm{MtCO}_{2}\right)$.

\begin{tabular}{|c|c|c|c|c|c|c|c|c|}
\hline \multirow[t]{2}{*}{ Province } & \multicolumn{4}{|c|}{ Emissions embodied in exports $\left(\mathrm{MtCO}_{2}\right)$} & \multicolumn{4}{|c|}{ Shares of provincial export-embodied emissions (\%) } \\
\hline & 2002 & 2007 & 2010 & 2014 & 2002 & 2007 & 2010 & 2014 \\
\hline Beijing & 13.65 & 19.64 & 21.27 & 8.87 & 2.34 & 1.09 & 1.30 & 0.67 \\
\hline Tianjin & 17.63 & 31.92 & 17.21 & 11.47 & 3.02 & 1.77 & 1.05 & 0.86 \\
\hline Hebei & 17.66 & 54.04 & 58.38 & 58.05 & 3.03 & 3.00 & 3.58 & 4.36 \\
\hline Shanxi & 8.41 & 24.30 & 18.63 & 10.62 & 1.44 & 1.35 & 1.14 & 0.80 \\
\hline Inner Mongolia & 4.40 & 11.97 & 16.16 & 8.00 & 0.75 & 0.66 & 0.99 & 0.60 \\
\hline Liaoning & 59.47 & 86.96 & 53.95 & 23.68 & 10.19 & 4.83 & 3.31 & 1.78 \\
\hline Jilin & 3.74 & 5.25 & 15.75 & 5.35 & 0.64 & 0.29 & 0.97 & 0.40 \\
\hline Heilongjiang & 5.56 & 8.95 & 10.05 & 3.82 & 0.95 & 0.50 & 0.62 & 0.29 \\
\hline Shanghai & 47.56 & 101.44 & 67.94 & 61.44 & 8.15 & 5.63 & 4.16 & 4.62 \\
\hline Jiangsu & 83.24 & 346.76 & 338.56 & 255.33 & 14.27 & 19.26 & 20.75 & 19.19 \\
\hline Zhejiang & 73.88 & 263.48 & 203.65 & 144.51 & 12.66 & 14.63 & 12.48 & 10.86 \\
\hline Anhui & 5.22 & 10.20 & 15.11 & 23.99 & 0.90 & 0.57 & 0.93 & 1.80 \\
\hline Fujian & 9.29 & 36.65 & 29.56 & 33.07 & 1.59 & 2.04 & 1.81 & 2.49 \\
\hline Jiangxi & 1.10 & 3.00 & 4.28 & 5.59 & 0.19 & 0.17 & 0.26 & 0.42 \\
\hline Shandong & 71.81 & 284.55 & 207.04 & 144.79 & 12.31 & 15.80 & 12.69 & 10.88 \\
\hline Henan & 7.70 & 20.06 & 28.13 & 51.90 & 1.32 & 1.11 & 1.72 & 3.90 \\
\hline Hubei & 1.90 & 7.23 & 10.23 & 9.00 & 0.33 & 0.40 & 0.63 & 0.68 \\
\hline Hunan & 1.97 & 5.49 & 7.84 & 6.46 & 0.34 & 0.30 & 0.48 & 0.49 \\
\hline Guangdong & 132.71 & 434.47 & 453.89 & 394.45 & 22.75 & 24.13 & 27.82 & 29.65 \\
\hline Guangxi & 1.26 & 4.11 & 5.50 & 6.17 & 0.22 & 0.23 & 0.34 & 0.46 \\
\hline Hainan & 0.27 & 0.49 & 0.61 & 3.15 & 0.05 & 0.03 & 0.04 & 0.24 \\
\hline Chongqing & 1.10 & 3.00 & 3.60 & 18.66 & 0.19 & 0.17 & 0.22 & 1.40 \\
\hline Sichuan & 3.64 & 7.19 & 8.10 & 11.18 & 0.62 & 0.40 & 0.50 & 0.84 \\
\hline Guizhou & 1.30 & 4.11 & 3.36 & 2.76 & 0.22 & 0.23 & 0.21 & 0.21 \\
\hline Yunnan & 1.24 & 4.60 & 6.02 & 3.92 & 0.21 & 0.26 & 0.37 & 0.29 \\
\hline Shaanxi & 2.76 & 5.66 & 11.03 & 14.12 & 0.47 & 0.31 & 0.68 & 1.06 \\
\hline Gansu & 1.23 & 4.79 & 2.97 & 1.76 & 0.21 & 0.27 & 0.18 & 0.13 \\
\hline Qinghai & 0.09 & 0.49 & 0.76 & 0.83 & 0.01 & 0.03 & 0.05 & 0.06 \\
\hline Ningxia & 0.82 & 2.15 & 4.63 & 2.68 & 0.14 & 0.12 & 0.28 & 0.20 \\
\hline Xinjiang & 2.77 & 7.69 & 7.27 & 4.88 & 0.47 & 0.43 & 0.45 & 0.37 \\
\hline Total & 583 & 1801 & 1631 & 1331 & 100 & 100 & 100 & 100 \\
\hline
\end{tabular}

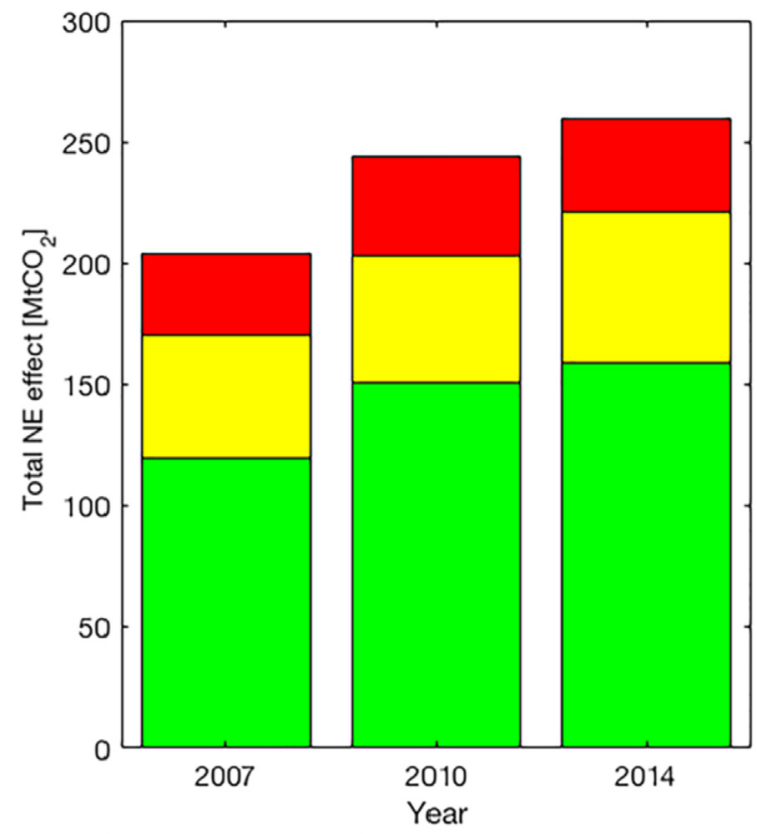

Supply-Chain $\square$ Electricity Transmission $\square$ Intra-regional

Fig. 3. Total impact of $\mathrm{NE}$ on $\mathrm{CO}_{2}$ emissions embodied in exports by three propagation effects (2007-2014).

impact. Although the share of supply-chain effect in Hebei reduced to $38 \%$ in 2014 , it made up a much larger share of its total emission savings than its intra-regional effect. Since Hebei has become China's workshop and a major manufacturing base, neighboring provinces (e.g. Shanxi and Inner Mongolia) have been the primary providers of intermediate products for Hebei's exports (Wang et al. 2017). Overall, the expansion of wind power in the northern provinces after 2007 helps Hebei to reduce export-embodied emissions.

\subsection{Intra-regional effect of non-fossil energy development}

Since the intra-regional effect reflects the influence of NE development in the exporting region itself, and its spatial distribution is consistent with the distribution of China's NE resources at the provincial level, this study further splits the intra-regional effect by NE types. Fig. 5 reports the intra-regional effect in twelve important trade provinces by NE type over the study period. The most important trade provinces, Guangdong, Zhejiang and Jiangsu, tend to be influenced by the development of nuclear power, as nuclear power is mostly located on or near the eastern coastline. From 2007 to 2014, the intra-regional effect in Liaoning and Fujian increased rapidly by $109 \%$ and $28 \%$ respectively, with the construction of nuclear power stations in both provinces. The development of nuclear power was responsible for $45 \%$ and $24 \%$ of their total intra-regional effects respectively in 2014. Hydropower had the largest impact in lowering emissions in the southwestern provinces. The impact of hydropower accounted for about 99\% of the intra-regional effects of Hubei, Sichuan, Yunnan, and Guangxi during the period 2007-2014. Wind power development drove significant reductions in embodied emissions of Shanghai, Shandong, and Hebei. The effect of wind power accounted for more than $90 \%$ of Shanghai's total intra-regional effect between 2007 and 2014. The share of emission reductions from wind power in Shandong increased from 54\% in 2007 to $96 \%$ in 2010, and then decreased to $93 \%$ in 2014 . In 2014, the share of the wind power 


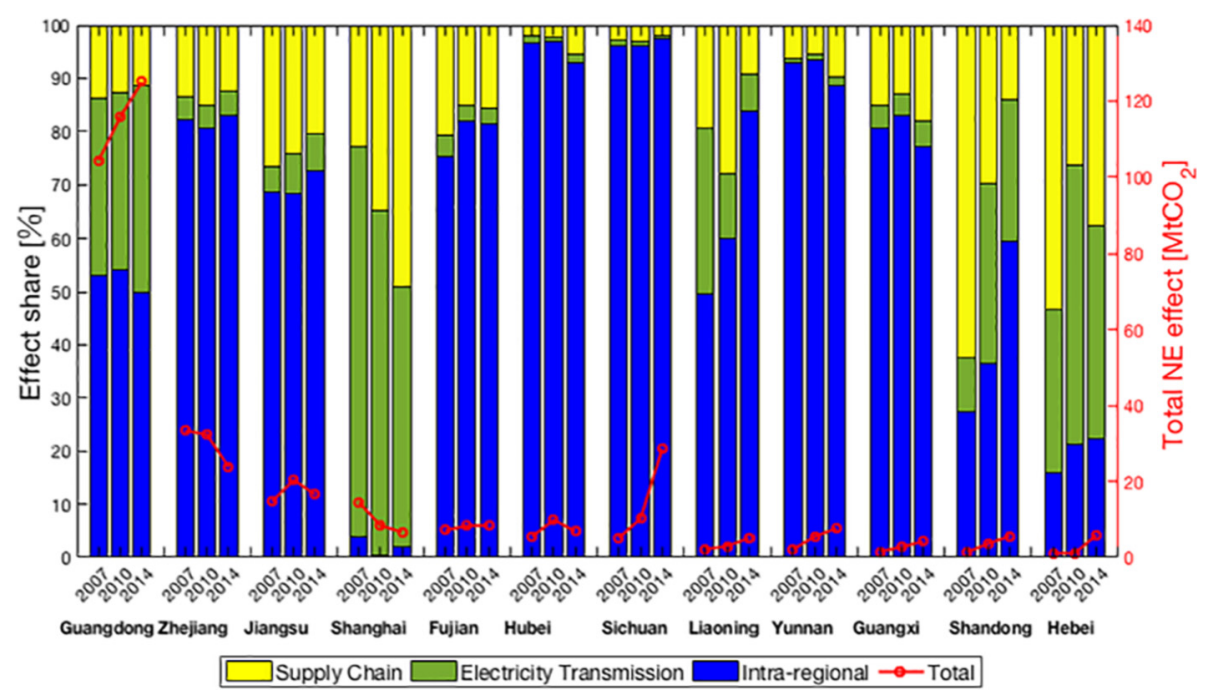

Fig. 4. Largest impacts of $\mathrm{NE}$ on $\mathrm{CO}_{2}$ emissions embodied in exports in 12 provinces (2007-2014).

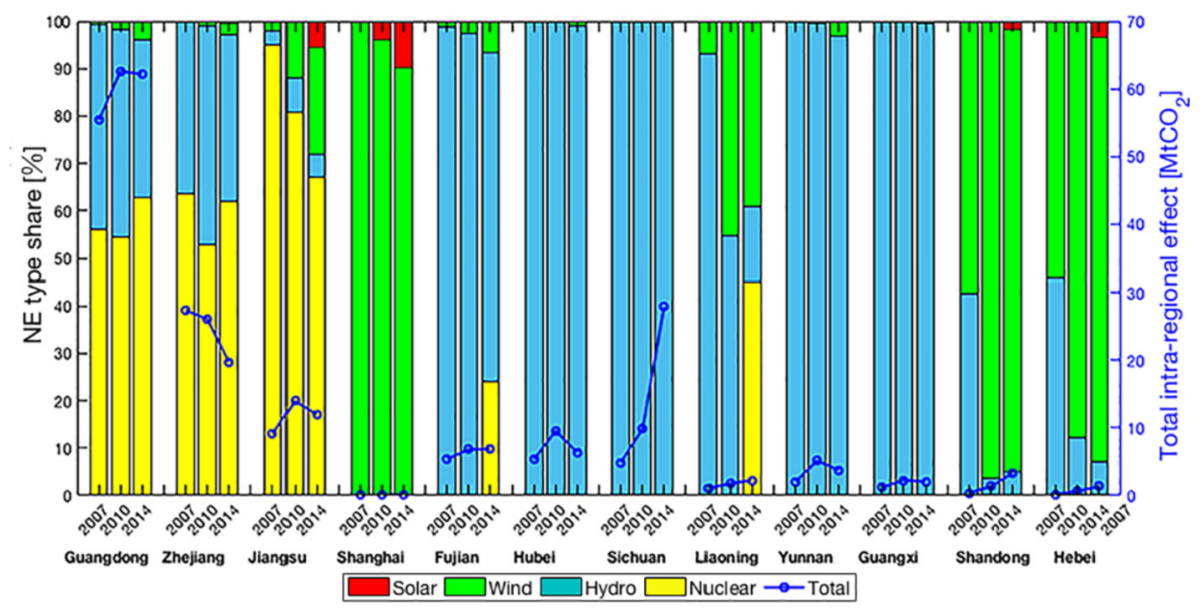

Fig. 5. Intra-regional effects in 12 important provinces by NE type (2007-2014).

impact in Hebei's total intra-regional effect increased from $54 \%$ in 2007 to 90\%. The impact of solar power in Shanghai by 2014 remained small but accounted for $10 \%$ of the total intra-regional effect by 2014.

\subsection{Electricity transmission and impact of non-fossil electricity}

Given the observed, substantial provincial differences in NE development, it is interesting to further investigate how electricity transmission brought about these emission reductions. Fig. 6 presents the $\mathrm{CO}_{2}$ impact of electricity transmission among eight, aggregated regions (listed in Table A.3 of Appendix A). In general, electricity transmission resulted in a relatively small reduction of emissions in the Southwest and Central regions, while increased electricity imports resulted in a large reduction of $\mathrm{CO}_{2}$ emissions in the South Coast and East Coast regions.

Mitigated emissions were seen largely in the South Coast and East Coast regions as electricity transmission infrastructure focused on bringing in hydropower from the Southwest and Central regions to the South Coast and East Coast regions. Regardless of the electricity transmission from the Southwest region to the South Coast region, overall $\mathrm{CO}_{2}$ emissions in the South region increased by
22.51 Mt in 2007, 30.16 Mt in 2010, and 41.08 Mt in 2014. Due to the electricity transmission from the Central region to the East Coast region, $\mathrm{CO}_{2}$ emissions in the East Coast region could be reduced by 10.10 Mt in 2007, 5.17 Mt in 2010, and 3.26 Mt in 2014. The utilization of transmission lines from the North region to the East Coast region facilitated the expansion of wind power in the North region, resulting in a reduction of $0.69 \mathrm{Mt}$ in 2010 and $0.72 \mathrm{Mt}$ in 2014. Also, after 2010, the reduction of $\mathrm{CO}_{2}$ emissions in the North region due to the electricity transmission effect was mostly related to the electricity transmission from the Northwest region, with mitigations of $0.95 \mathrm{Mt}$ in 2010 and $0.98 \mathrm{Mt}$ in 2014. However, the exported electricity in the Northwest region had limited effect on the exportembodied emissions in the East Coast and South Coast regions. Therefore, the government may need to enlarge the outward transmission capacity from the Northwest region and concentrate the connections to the East Coast and South Coast regions.

\subsection{Supply chain and impact of non-fossil electricity development}

Given the close linkage between production in the coastal eastern region and inputs from the central and western regions (Zhao et al., 2015), and the fact that NE is predominantly located in 


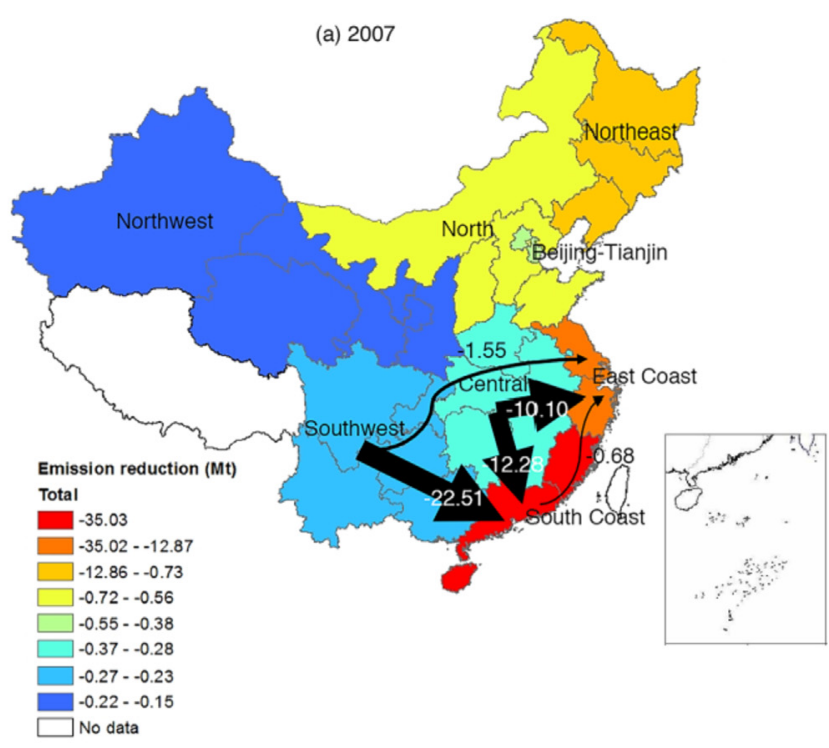

(b) 2010
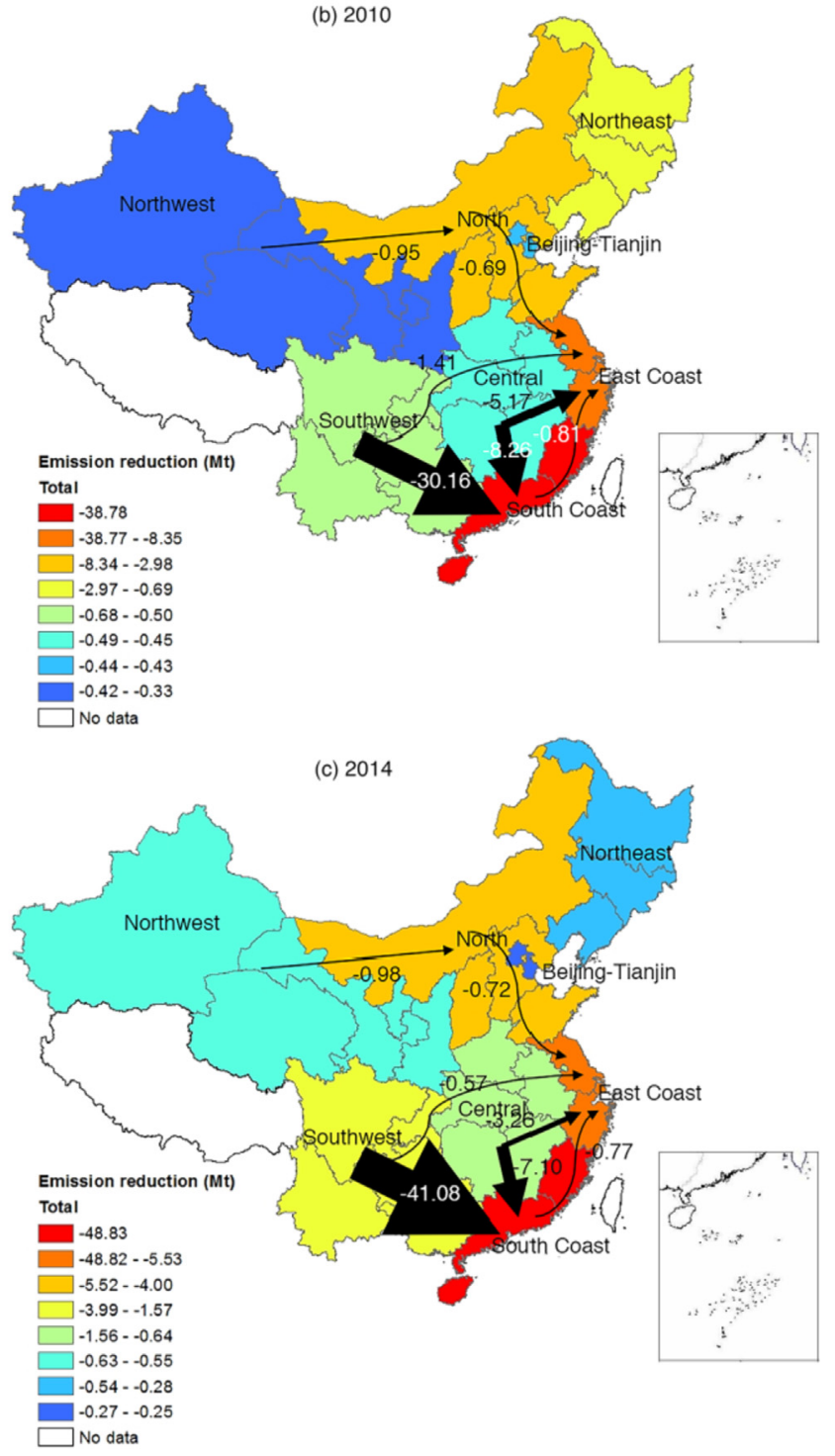

Fig. 6. Largest impacts of inter-regional electricity transmission among eight, aggregated regions (2007-2014). Note: The shading in each region indicates the total impact induced by electricity transmission.

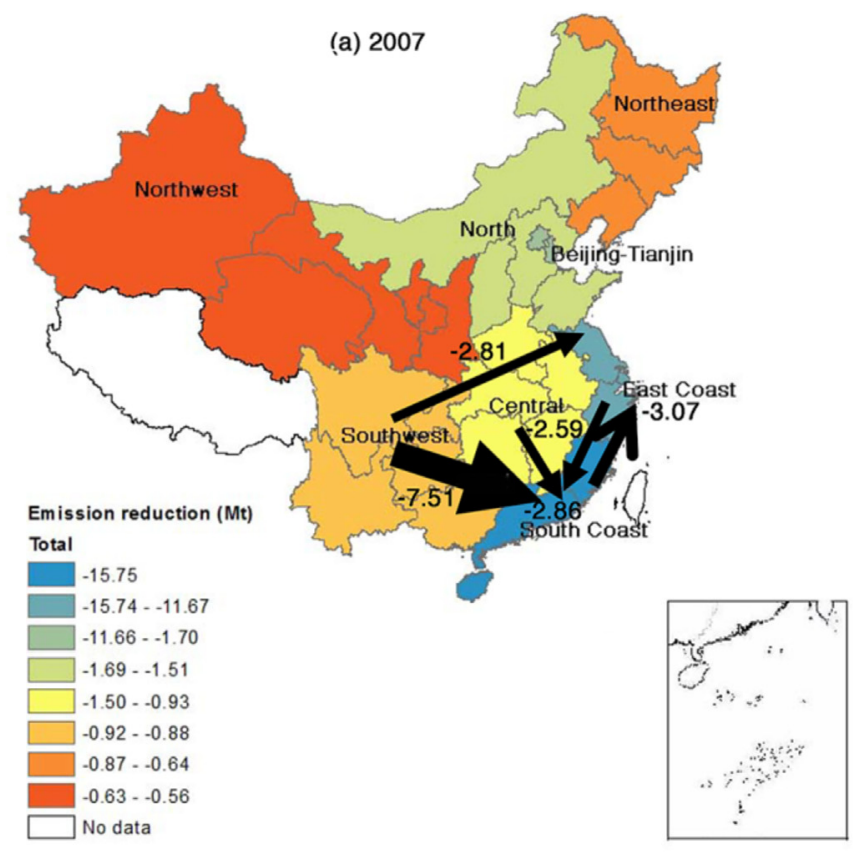

(b) 2010

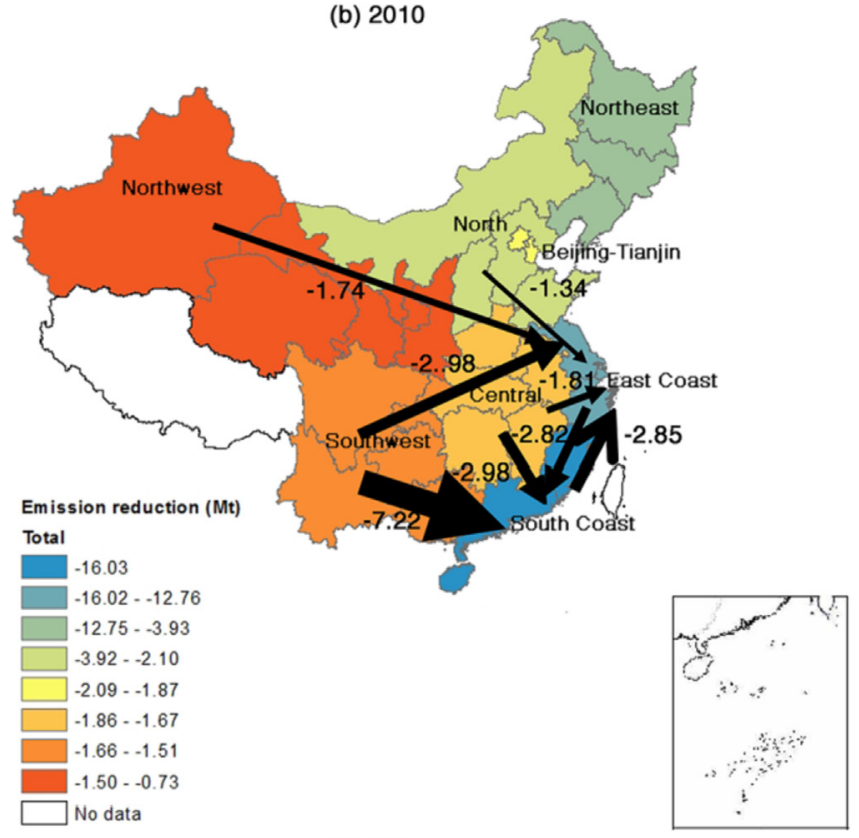

(c) 2014

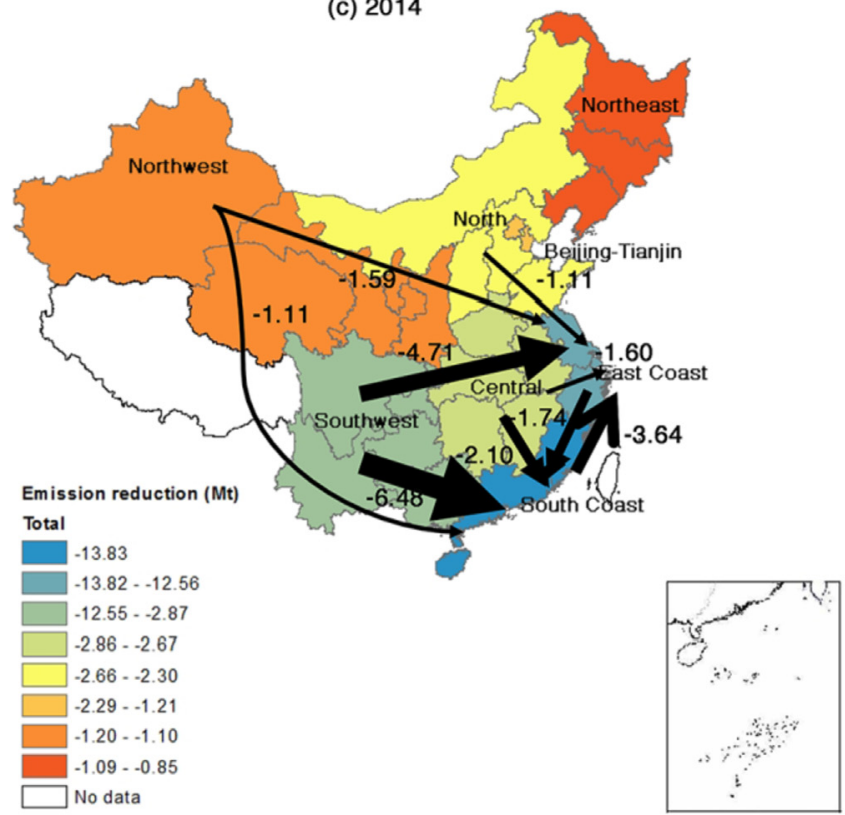

Fig. 7. Largest supply-chain effects among eight, aggregated regions (2007-2014). The shading in each region indicates the nonlocal impact induced by NE development in other regions. 
the western and central regions (as shown in Fig. 2), investigating the impact of $\mathrm{NE}$ development on inter-regional $\mathrm{CO}_{2}$ emission transfers gives further insight. It is noted that the supply-chain effect is the change of export-embodied carbon emissions due to the non-fossil electricity development in other regions rather than the exporting region, transmitted through the purchase of goods and services other than electricity. It is a bulk quantity. The Fig. 7 presents the impact of $\mathrm{NE}$ development on inter-regional $\mathrm{CO}_{2}$ flows induced by exports among eight regions.

In 2007, NE development in the Southwest region resulted in a significant reduction of $\mathrm{CO}_{2}$ embodied in the intermediate inputs to support the exports of the South Coast $(7.51 \mathrm{Mt})$ and East Coast $(2.81 \mathrm{Mt})$ regions. $\mathrm{CO}_{2}$ emissions in the South Coast region induced by the exports of the East Coast region showed reductions of 3.07 Mt. The inter-regional $\mathrm{CO}_{2}$ flow from the Central region to the South Coast region showed reductions of $2.89 \mathrm{Mt}$. In 2010, $\mathrm{CO}_{2}$ emissions in the Southwest region induced by the exports of the South Coast region saw the largest impacts (7.22 Mt), with the inter-regional $\mathrm{CO}_{2}$ flow from the Southwest region to the East Coast region the second largest $(2.98 \mathrm{Mt})$. The reason is that the East Coast and South Coast regions are generally located downstream in the supply chain, and need large resources from other regions. The remarkable reduction in the inter-regional $\mathrm{CO}_{2}$ flow from the North region to the East Coast region $(1.34 \mathrm{Mt})$ were primarily due to wind power development, evidenced by the large increases of wind power generation in Hebei and Shandong. In addition, with wind power development in the Northwest region, the indirect impacts of NE development in the Northwest region on the exportembodied emissions in the East Coast region expanded to $1.74 \mathrm{Mt}$. In 2014, the impact of $\mathrm{NE}$ development on $\mathrm{CO}_{2}$ flows from the Central region to the East Coast and South Coast regions declined slightly. This is consistent with previous findings that the emissions embodied in the net trade from the Central region to the East Coast region has declined after 2010 due to the changes in regional production and consumption structure (Mi et al., 2017). However, the impact of NE on the $\mathrm{CO}_{2}$ flow from the Southwest region to the South Coast region was still the largest $(6.48 \mathrm{Mt})$. Moreover, the majority of NE impacts were seen within the $\mathrm{CO}_{2}$ flow from the Southwest region to the East Coast region, reaching a maximum reduction of $4.71 \mathrm{Mt} \mathrm{CO}_{2}$. These show that the NE development in other regions is still significant for reducing embodied emissions in the East Coast region.

Based on the results in Section 5.3, due to the distribution of NE resources, the supply-chain effects in Shanghai and Hebei were much larger than their intra-regional effects. In order to analyze the most noteworthy inter-regional $\mathrm{CO}_{2}$ flows through which nonlocal $\mathrm{NE}$ development exerted significant impacts on the embodied emissions in Hebei and Shanghai, the key inter-regional $\mathrm{CO}_{2}$ flows (as shown in Table 2) are picked up. Hebei saw the largest emission reductions due to Guangdong's NE development in 2007 (0.07 Mt), increasing to $0.10 \mathrm{Mt}$ in 2010 . Since the intermediate input of Hebei was mainly supplied by neighboring provinces, wind power development in Inner Mongolia started to have a major role in Hebei's $\mathrm{CO}_{2}$ savings after 2010, driving a reduction of $0.10 \mathrm{Mt}$ in 2010, and 0.32 Mt in 2014. In 2007, the nonlocal impact of Shanghai generally came from neighboring provinces (Zhejiang and Jiangsu). In 2007, NE development in Zhejiang resulted in a reduction of $0.70 \mathrm{Mt} \mathrm{CO}_{2}$ embodied in Shanghai's exports via inter-regional economic linkages, expanding to $1.21 \mathrm{Mt}$ in 2014.

\subsection{Summary and discussion}

This study applies a hybrid MRIO model with inter-provincial electricity transmission to assess the impact of NE development on the carbon emissions embodied in the exports of China's 30
Table 2

Largest supply-chain effects for Hebei and Shanghai $\left(\mathrm{MtCO}_{2}\right)$.

\begin{tabular}{lllll}
\hline Year & Province $\mathrm{r}$ & Province s & effect induced by province $\mathrm{r}$ & Total effect \\
\hline 2007 & Guangdong & Hebei & -0.07 & -0.58 \\
& Sichuan & & -0.06 & \\
& Zhejiang & & -0.06 & -3.32 \\
& Zhejiang & Shanghai & -0.78 & \\
& Guangdong & & -0.64 & -0.80 \\
& Sichuan & & -0.28 & \\
Inner Mongolia & Hebei & -0.10 & -2.92 \\
& Guangdong & & -0.10 & \\
& Sichuan & & -0.07 & -2.24 \\
& Guangdong & Shanghai & -0.56 & \\
& Zhejiang & & -0.47 & -3.27 \\
Sichuan & & -0.24 & \\
Inner Mongolia & Hebei & -0.32 & -0.30 & \\
Sichuan & & -0.28 & \\
& Hubei & & -1.21 & \\
& Zhejiang & Shanghai & & \\
& Jiangsu & & -0.77 & \\
Hubei & & -0.16 &
\end{tabular}

Note: Column 4 indicates that the impact of NE development in province $r$ on export-embodied emissions of province s. Column 5 indicates that the total impact of NE development in other provinces on export-embodied emissions of provinces.

provinces. The changes in carbon emissions are estimated by comparing historical data with a counterfactual without NE development. Such an investigation presents a comprehensive picture of NE impacts, including historical evolution, spatial distribution, mode of propagation and energy types, which can be used to test the applicability of national $\mathrm{NE}$ policies implementation.

Large-scale $\mathrm{NE}$ development reduced export-embodied $\mathrm{CO}_{2}$ emissions by $203 \mathrm{Mt}, 244 \mathrm{Mt}$, and $259 \mathrm{Mt}$ export-embodied $\mathrm{CO}_{2}$ in 2007,2010 , and 2014 respectively, which was equivalent to $11.3 \%$ in 2007, $14.9 \%$ in 2010 and $19.5 \%$ in 2014 of the total carbon emissions embodied in exports, respectively. Provinces with a large amount of export-embodied emissions, such as Guangdong, Jiangsu, and Zhejiang, have seen a relatively high carbon impact of NE as nuclear power and hydropower have been expanded. This shows that the expansion of NE in China has significantly reduced the potential carbon leakage in international trade. However, the provincial carbon impact of NE did not correlate directly with the distribution of export-embodied emissions. Several major trade provinces, such as Shandong and Hebei, had a relatively low carbon impact of NE. In contrast, provinces such as Hubei, Sichuan, and Yunnan, which had small amounts of export-embodied emissions, have driven large decreases in $\mathrm{CO}_{2}$ emissions as hydropower has expanded over a long period.

Furthermore, NE impacts are divided into three modes: intraregional, electricity transmission, and supply-chain. Since the intra-regional effect matches up well with NE resource across regions in China, most provinces with large NE impacts were mainly affected by intra-regional NE expansion. This study highlights the relationship between electricity transmission and the carbon impacts of NE. Electricity transmission led to $\mathrm{CO}_{2}$ emission reductions of $50 \mathrm{Mt}$ in 2007, increasing to $62 \mathrm{Mt}$ in 2014. Overall, the exported electricity of the Central and Southwest regions made a large contribution to reducing the emission tensions in the East Coast and South Coast regions. The exported electricity of the Northwest region could also effectively reduce the $\mathrm{CO}_{2}$ emissions in the North region. Moreover, the facilitation of mitigation due to electricity transmission depends on the level of NE development in neighboring regions. Initially, electricity transmission might lead to small emission reductions due to increasing imports of low-cost coalfired electricity. As the amount of $\mathrm{NE}$ increases, $\mathrm{CO}_{2}$ emissions will 
start to reduce. This study gives further resolution of the impact of $\mathrm{NE}$ development on inter-regional $\mathrm{CO}_{2}$ flows, and traces indirect impacts induced by other regions' NE development. NE development in the Central and Southwest regions brought about a significant reduction of export-embodied $\mathrm{CO}_{2}$ emissions in the South Coast and East Coast regions, as close economic linkages existed between them. NE development in neighboring provinces resulted in a mitigation of export-embodied $\mathrm{CO}_{2}$ emissions in Hebei and Shanghai via inter-regional economic connections.

Fruitful directions for further research could focus on the carbon impact of expansion of NE infrastructure, as this work only explores the operational, 'in-use' effect of NE. Second, the impact of NE development on the carbon emissions embodied in China's exports to particular importing countries (i.e. the United States) would be a valuable further effort. Finally, this study provides a quantitative framework that can be applied to other countries. Further studies could also be expanded by performing a spatially-explicitly, timeseries analysis over a longer period.

\section{Conclusions and policy implications}

This study explores the regional patterns of the impact of NE expansion on China's export-embodied carbon emissions. The contribution of electricity transmission and supply-chain effects to overall $\mathrm{CO}_{2}$ savings is analyzed. The findings highlight the impact of $\mathrm{NE}$ development on inter-regional $\mathrm{CO}_{2}$ flows, and the importance of electricity transmission, which helps clarify how the impact of NE development is generated and transmitted. Considering the rapid expansion of NE in China, a historical investigation of the evolution of NE effects at the provincial level informs energy planning and management. This knowledge can be used to make further scenarios for the future, and serves as a basis for the evaluation of $\mathrm{NE}$ regulations. Based on the results above, several policy implications can be given.

First, NE policies need to take spatial features into consideration given China's regional heterogeneity. Since more than half of China's export-embodied emissions were driven by top trade provinces, a better understanding of the obvious regional differences in export-embodied emissions will support a wider range of NE development options, and is beneficial to national and global climate policy. Specifically, if these top trade provinces have reduced export-embodied emissions due to NE development, that also triggers to a change in the total national export-embodied emissions, which then has flow-on impacts on global carbon emissions. Thus, when formulating NE development plans, paying more attention to provinces with a low-level of NE development and fast-growing outsourcing emissions would contribute to developing reasonable NE targets among provinces. For example, since NE has not been fully exploited in Hebei and Shandong, a reasonable regional NE development plan could be formulated for Hebei and Shandong to reduce the carbon leakage in international trade in the long term.

Second, the improvement of electricity transmission is an optimal way to increase carbon savings brought by NE development. The basic spatial structure of electricity transmission, in which the coastal regions imported NE from the inland regions, has been established in China. However, the current electricity transmission grid for wind and solar power is limited. NE delivery across regions still relies on hydropower. Though there are good wind and solar resources in the Northwest region, they are not yet transmitted to the East Coast region. Moreover, the expansion of wind power in the Northeast region does not obviously impact the carbon emissions in the North region. These results are important for electricity transmission system designers. If the expansion of wind and solar power continues, two inter-regional electricity transmission lines in different directions would need to be considered.

Third, significant export-embodied emission reductions in the coastal regions can be obtained from the NE development in the inland regions via inter-regional economic linkages. This provides useful insights regarding to the role of NE development in decarbonizing global supply chains. Supply-chain and electricity transamination effects are heavily intertwined, as they both strengthen the transfer of carbon impacts due to NE development from one region to another. However, these two different effects, inter-regional economic relations and electricity transmission, are generally addressed by different policy tools. This means that when planning NE expansion, both effects should be considered and proposed policies should be synergistic. Since the inland regions generally have low mitigation costs due to abundant resources, diffusion of NE technologies there may reduce the nationwide mitigation costs. The supply-chain effect of NE development is more significant for neighboring regions. This suggests that policies promoting the joint control of export-embodied emissions in surrounding regions can complement existing approaches to intensify the impact of NE development on reducing export-embodied emissions.

Table A.1

Comparison between the different studies of China's export-embodied carbon emissions based on MRIO model.

\begin{tabular}{|c|c|c|c|c|}
\hline Author/s & Data Year & Methods & Research Topic & Main Results \\
\hline Qi et al., 2014a, b & 2007 & MRIO and CGE & $\begin{array}{l}\text { The impact of economic restructuring on export- } \\
\text { embodied emissions }\end{array}$ & $\begin{array}{l}\text { Increasing export taxes could decrease } 44 \mathrm{MtCO}_{2} \\
\text { embodied emissions, equivalent to a } 3.7 \% \text { decrease. }\end{array}$ \\
\hline Liu et al., 2016a & 2007 & IO & $\begin{array}{l}\text { The assessment of export embodied emissions using } \\
\text { firm heterogeneity information }\end{array}$ & $\begin{array}{l}\text { Ignoring firm heterogeneity caused China's export- } \\
\text { embodied } \mathrm{CO}_{2} \text { emissions in } 2007 \text { to be } \\
\text { overestimated by } 20 \% \text {. }\end{array}$ \\
\hline Tang et al., 2017 & 2012 & $\begin{array}{l}\text { IO and multi-objective } \\
\text { programming }\end{array}$ & $\begin{array}{l}\text { The impact of trade restructuring on export- } \\
\text { embodied emissions }\end{array}$ & $\begin{array}{l}\text { Trade restructuring could reduce China's net export- } \\
\text { embodied emissions by } 3.26 \%, 9.33 \% \text { and } 14.58 \% \\
\text { under low, moderate and high scenarios, } \\
\text { respectively. }\end{array}$ \\
\hline Zhao et al., 2017b & $2000-2014$ & MRIO & $\begin{array}{l}\text { The carbon impact of trade between China and major } \\
\text { trading partners in the Asia-Pacific }\end{array}$ & $\begin{array}{l}\text { During 2000-2006, the expansion of China's } \\
\text { intermediate exports with major trade partners in } \\
\text { the Asia-Pacific increased China's carbon emissions, } \\
\text { with annual growth rates of } 20 \% \text {. After 2006, the } \\
\text { impacted carbon emissions fluctuated around } 400 \\
\mathrm{MtCO}_{2} \text {. }\end{array}$ \\
\hline Weber et al., 2008 & $1987-2005$ & IO & The trend of export-embodied emissions & \\
\hline
\end{tabular}


Table A.1 (continued)

\begin{tabular}{|c|c|c|c|c|}
\hline Author/s & Data Year & Methods & Research Topic & Main Results \\
\hline Xu et al., 2011 & $2002-2008$ & IO and SDA & $\begin{array}{l}\text { Driving factors of export-embodied emissions } \\
\text { (emission intensity, economic structure, export } \\
\text { composition and export volume) }\end{array}$ & $\begin{array}{l}\text { In } 2005 \text {, almost one-third of China's emissions } \\
\left(1700 \mathrm{Mt} \mathrm{CO}_{2}\right) \text { were due to the production of exports. } \\
\text { During } 2002-2008 \text {, the increase of export-embodied } \\
\text { emissions was attributable to the change of export } \\
\text { composition. The decline in emission intensity } \\
\text { counterweighed the growth of embodied emissions. }\end{array}$ \\
\hline Liu et al., 2017 & 2007 & IO & $\begin{array}{l}\text { Estimation of export-embodied emissions using a } \\
\text { non-competitive import IO approach }\end{array}$ & $\begin{array}{l}\text { Using a non-competitive import IO approach, the net } \\
\mathrm{CO}_{2} \text { emissions embodied in China's trade in } 2007 \\
\text { ( } 400 \mathrm{Mt}) \text { were much lower than previous } \\
\text { estimations. }\end{array}$ \\
\hline Tian and Lin, 2017 & $2002-2012$ & Hybrid IO & $\begin{array}{l}\text { The impact of green productivity growth on } \\
\text { emissions embodied in China's industrial exports }\end{array}$ & $\begin{array}{l}\text { The total emissions embodied in China's industrial } \\
\text { exports increased more than } 100 \% \text { during } 2002 \\
\text {-2007, with small variation during } 2007-2012 \text {. } \\
\text { Technological improvement could reduce embodied } \\
\text { emissions. }\end{array}$ \\
\hline Vetőné Mózner & 2010 & MRIO & $\begin{array}{l}\text { The relationship of } \mathrm{CO}_{2} \text { emission embodied in } \\
\text { exports and embodied in imports }\end{array}$ & $\begin{array}{l}\text { The production-based } \mathrm{CO}_{2} \text { emissions are lower } \\
\text { compared to the consumption-based emissions in } \\
\text { the analyzed countries. }\end{array}$ \\
\hline Xu et al., 2017 & 2011 & MRIO & The estimation of export-embodied emissions & $\begin{array}{l}\text { The result based on traditional methods caused a } \\
\text { substantial overestimation, equaling to almost one- } \\
\text { third of the total export-embodied emissions. }\end{array}$ \\
\hline Peters et al., 2011 & $1990-2008$ & MRIO & The emission transfers via international trade & $\begin{array}{l}\text { The emissions induced by the production of exports } \\
\text { in China accounted for } 18 \% \text { of the growth in the } \\
\text { global } \mathrm{CO}_{2} \text { emissions. }\end{array}$ \\
\hline Deng et al., 2016 & 1995-2009 & MRIO and SDA & $\begin{array}{l}\text { Driving factors analysis (emission coefficient, } \\
\text { Leontief inverse matrix and export scale) }\end{array}$ & $\begin{array}{l}\text { The changes of direct emission coefficients led to the } \\
\text { decrease in embodied emissions, while the } \\
\text { variations of Leontief inverse matrix led to the } \\
\text { increase in embodied emissions }\end{array}$ \\
\hline Andersson, 2018 & 1995-2008 & MRIO, Statistical test & $\begin{array}{l}\text { The impact of China policy reforms on export- } \\
\text { embodied emissions }\end{array}$ & $\begin{array}{l}\text { Trade liberalization, environmental institutions and } \\
\text { exchange rate policies were important institutional } \\
\text { factors illustrating the growth of embodied } \\
\text { emissions. }\end{array}$ \\
\hline Zhao et al., 2016 & 1995-2009 & MRIO, HEM, and SDA & $\begin{array}{l}\text { Driving factors of carbon emissions embodied in } \\
\text { China-US trade (emission intensity, energy use } \\
\text { structure, energy intensity, trade structure, } \\
\text { technology level, export market shares of final } \\
\text { products, total demand) }\end{array}$ & $\begin{array}{l}\text { "Trade structure of intermediate products at home" } \\
\text { and "export market shares of final products at home" } \\
\text { factors showed the largest positive effects on } \\
\text { embodied emissions. }\end{array}$ \\
\hline Zhao et al., 2017a & 1995-2009 & MRIO and GLMDI & $\begin{array}{l}\text { Driving factors of } \mathrm{CO}_{2} \text { emissions per value added } \\
\text { (EpV) in the trade of China and USA (emission } \\
\text { coefficient, IO structure and value added coefficient) }\end{array}$ & $\begin{array}{l}\text { The EpV of China's exports was } 6.35 \text { times that of } \\
\text { USA in } 1995 \text {, and this ratio reached } 7.43 \text { in } 2009 \text {. IO } \\
\text { structure had the largest effect on the expansion of } \\
\text { EpV gaps between China and USA. }\end{array}$ \\
\hline Wu et al., $2016 b$ & 2000-2009 & $\begin{array}{l}\text { Two region MRIO and } \\
\text { LMDI }\end{array}$ & $\begin{array}{l}\text { Driving factors of changes of } \mathrm{CO}_{2} \text { emissions } \\
\text { embodied in China-Japan trade (export volume, } \\
\text { export structure, emission intensity) }\end{array}$ & $\begin{array}{l}\text { Export volume was the main driver for the increase } \\
\text { of embodied emissions, while emission intensity } \\
\text { reduction contributed to reducing embodied } \\
\text { emissions. }\end{array}$ \\
\hline Li and Hewitt, 2008 & 2004 & IO & $\begin{array}{l}\text { The impact of China-UK trade on global } \mathrm{CO}_{2} \\
\text { emissions }\end{array}$ & $\begin{array}{l}\text { China-UK trade led to an additional } 117 \mathrm{Mt} \text { of } \mathrm{CO}_{2} \text { to } \\
\text { the global } \mathrm{CO}_{2} \text { emissions in } 2004 \text {, accounting for } 19 \% \\
\text { of the UK's total emissions and } 0.4 \% \text { of the global } \\
\text { emissions. }\end{array}$ \\
\hline Su and Ang, 2010 & 1997 & MRIO & $\begin{array}{l}\text { The impact of spatial aggregation on export- } \\
\text { embodied emissions }\end{array}$ & $\begin{array}{l}\text { The impact of spatial aggregation on the embodied } \\
\text { emissions could be achieved through affecting the } \\
\text { total emission intensities. }\end{array}$ \\
\hline Feng, 2012 & 2007 & $\begin{array}{l}\text { MRIO } \\
\text { and SDA }\end{array}$ & $\begin{array}{l}\text { Driving factors of provincial } \mathrm{CO}_{2} \text { emissions embodied } \\
\text { in exports }\end{array}$ & $\begin{array}{l}\text { Exports in the developed regions were supported by } \\
\text { emissions occurring in the less developed regions of } \\
\text { China. }\end{array}$ \\
\hline Guo et al., 2012, & 2002 & MRIO & $\begin{array}{l}\text { Characteristics of export-embodied } \mathrm{CO}_{2} \text { emissions at } \\
\text { the provincial level }\end{array}$ & $\begin{array}{l}\text { The eastern region accounted for a large proportion } \\
\text { in China's export-embodied } \mathrm{CO}_{2} \text { emissions. The net } \\
\text { transfer of embodied emissions was from the eastern } \\
\text { region to the central region. }\end{array}$ \\
\hline Meng et al., 2013 & 2002 and 2007 & MRIO & $\begin{array}{l}\mathrm{CO}_{2} \text { emissions spillover effects caused by partner } \\
\text { region's exports }\end{array}$ & $\begin{array}{l}\text { The exports of the South Coast and East Coast regions } \\
\text { had the largest spillover effect on } \mathrm{CO}_{2} \text { emissions in } \\
\text { the other regions. }\end{array}$ \\
\hline $\begin{array}{l}\text { Weitzela and Ma, } \\
2014\end{array}$ & 2007 & MRIO & $\begin{array}{l}\text { The effect of export processing and inter-regional } \\
\text { trade on export-embodied emissions }\end{array}$ & $\begin{array}{l}\text { The estimated embodied emissions using the MRIO } \\
\left.\text { model ( } 1730 \mathrm{Mt} \mathrm{CO}_{2}\right) \text { and the model considering } \\
\text { export processing }\left(1630 \mathrm{Mt} \mathrm{CO}_{2}\right) \text { were both lower } \\
\text { than estimations of the standard IO model }(1782 \mathrm{Mt} \\
\left.\mathrm{CO}_{2}\right) \text { in } 2007 \text {. }\end{array}$ \\
\hline Jiang et al., 2015 & 2007 & MRIO and IDA & The determining factors of virtual carbon flows & $\begin{array}{l}\text { Trade balance and energy intensity were the two } \\
\text { largest factors of almost all regions' net carbon trades } \\
\text { and all large bilateral flows. }\end{array}$ \\
\hline Liu et al., 2015a & $1997-2007$ & MRIO & $\begin{array}{l}\text { The estimation of carbon emissions embodied in the } \\
\text { demand-supply chain for exports }\end{array}$ & $\begin{array}{l}\text { The largest inter-regional net transfer of embodied in } \\
\text { the demand-supply chain for export was from the } \\
\text { less developed regions to the developed regions. }\end{array}$ \\
\hline Tang et al., 2015 & 1997-2010 & MRIO & $\begin{array}{l}\text { The inter-regional spillover and feedback effects } \\
\text { induced by exports }\end{array}$ & $\begin{array}{l}\text { The strong spillover effects caused by exports } \\
\text { showed in the coastal regions, while the strong }\end{array}$ \\
\hline
\end{tabular}


Table A.1 (continued)

\begin{tabular}{|c|c|c|c|c|}
\hline Author/s & Data Year & Methods & Research Topic & Main Results \\
\hline & & & & $\begin{array}{l}\text { feedback effects caused by exports showed in the } \\
\text { inland regions. }\end{array}$ \\
\hline Wang et al., 2015 & 2007 & $\begin{array}{l}\text { MRIO and Kaya } \\
\text { decomposition analysis }\end{array}$ & $\begin{array}{l}\text { The impact of carbon flows among regions on } \\
\text { export-embodied emissions }\end{array}$ & $\begin{array}{l}\text { Almost } 40 \% \text { of the emissions embodied in the coastal } \\
\text { regions' exports occurred in the inland regions of } \\
\text { China in } 2007 \text { via inter-regional economic linkages. }\end{array}$ \\
\hline Duan et al., 2018 & 2012 & MRIO and ENA & The assessment of key carbon flows in China & $\begin{array}{l}\text { The carbon emissions in the most regions of China } \\
\text { were induced by the east's final demand. }\end{array}$ \\
\hline $\begin{array}{l}\text { Zhang and Tang, } \\
\qquad 2015\end{array}$ & $2007-2010$ & MRIO and LMDI & $\begin{array}{l}\text { Driving factors of carbon embodied in provincial } \\
\text { exports (emission intensity, IO structure, export } \\
\text { structure, regional distribution and export scale) }\end{array}$ & $\begin{array}{l}\text { During } 2007-2010 \text {, the decrease in the total export- } \\
\text { embodied emissions of most provinces was caused } \\
\text { by the change of IO structure. The decline of emission } \\
\text { intensity also decreased the export-embodied } \\
\text { emissions in most provinces, especially in the } \\
\text { eastern provinces. }\end{array}$ \\
\hline Liu et al., 2015b & 2007 & MRIO and IDA & $\begin{array}{l}\text { Driving factors of provincial export-embodied } \\
\text { emissions (trade volume, trade structure, emission } \\
\text { intensity) }\end{array}$ & $\begin{array}{l}\text { The net emissions embodied in China's exports were } \\
\text { mainly due to the coal-dominated energy structure } \\
\text { and the high energy intensity of some exporting } \\
\text { provinces and sectors. }\end{array}$ \\
\hline Mi et al., 2017 & $2007-2012$ & MRIO and SDA & $\begin{array}{l}\text { Driving factors of provincial export-embodied } \\
\text { emissions (trade volume, trade structure, emission } \\
\text { intensity) }\end{array}$ & $\begin{array}{l}\text { The export-embodied emissions declined during } \\
2007-2012 \text { due to the changes of production } \\
\text { structure and the improvement of production } \\
\text { efficiency. The net emission flows from the western } \\
\text { region to the eastern region declined due to the } \\
\text { expansion of consumption scale and the adjustment } \\
\text { of economic structure. }\end{array}$ \\
\hline
\end{tabular}

Table A.2

Sector classifications for the Chinese economy.

\begin{tabular}{ll}
\hline Code & Sector \\
\hline AGR & Agriculture \\
MC & Mining \\
FD & Food \\
TEX & Textile \\
TF & Processing of Timber and Furniture \\
PP & Paper and Paper Products \\
PC & Petroleum Refining and Coking \\
CHE & Chemical \\
NMP & Non-metallic Mineral Products \\
SPM & Smelting and Pressing of Metals \\
MP & Metal Products \\
GE & General Equipment \\
TE & Transport Equipment \\
EME & Electric Machinery and Equipment \\
EE & Electronic Equipment \\
IM & Instruments and Machinery of Cultural Activity and Office Work \\
OM & Other Manufacturing \\
ELE & Electricity \\
CON & Construction \\
TRA & Transportation \\
SE & Services \\
\hline
\end{tabular}

Table A.3

Region classifications.

\begin{tabular}{ll}
\hline Region & Province that included in each region \\
\hline Beijing-Tianjin & Beijing and Tianjin \\
North & Hebei, Shanxi, Inner Mongolia and Shandong \\
Northeast & Liaoning, Jilin and Heilongjiang \\
East Coast & Jiangsu, Shanghai and Zhejiang \\
Central & Henan, Anhui, Hunan, Hubei and Jiangxi \\
South Coast & Fujian, Guangdong and Hainan \\
Southwest & Sichuan, Chongqing, Guizhou, Yunnan and Guangxi \\
Northwest & Shaanxi, Gansu, Qinghai, Ningxia and Xinjiang \\
\hline
\end{tabular}

\section{References}

Andersson, F.N.G., 2018. International trade and carbon emissions: the role of Chinese institutional and policy reforms. J. Environ. Manag. 205, 29-39.

Behrens, P., Rodrigues, F.D.J., Brás, T., Silva, C., 2016. Environmental, economic, and social impacts of feed-in tariffs: a Portuguese perspective 2000-2010. Appl. Energy 173, 309-319.

Budzinski, M., Bezama, A., Thran, D., 2017. Monitoring the progress towards bioeconomy using multi-regional input-output analysis: the example of wood use in Germany. J. Clean. Prod. 161, 1-11.

Bullard and Herendeen, 1975. The energy cost of goods and services. Energy Pol. 3, $268-278$.

Cai, W., Mu, Y., Wang, C., Chen, J., 2014. Distributional employment impacts of renewable and new energy- A case study of China. Renew. Sustain. Energy Rev. 39, 1155-1163.

Caro, D., Pulselli, F.M., Borghesi, S., Bastianoni, S., 2017. Mapping the internationa flows of GHG emissions within a more feasible consumption-based framework. J. Clean. Prod. 147, 142-151.

Chen, Q., Kang, C.Q., Ming, H., Wang, Z., Xia, Q., Xu, G., 2014. Assessing the lowcarbon effects of inter-regional energy delivery in China's electricity sector Renew. Sustain. Energy Rev. 32, 671-683.

China Electric Power Yearbook Editorial Board (CEPYEB), 2003. China electric Power Yearbook 2002. China Electric Power Press, Beijing (in Chinese).

China Electric Power Yearbook Editorial Board (CEPYEB), 2008. China electric Power Yearbook 2007. China Electric Power Press, Beijing (in Chinese).

China Electric Power Yearbook Editorial Board (CEPYEB), 2011. China electric Power Yearbook 2010. China Electric Power Press, Beijing (in Chinese).

China Electric Power Yearbook Editorial Board (CEPYEB), 2015. China electric Power Yearbook 2014. China Electric Power Press, Beijing (in Chinese).

Chun, D., Woo, C., Seo, H., Chuang, Y., Hong, S., Kim, J., 2014. The role of hydrogen energy development in the Korean economy: an input-output analysis. Int. J. Hydrogen Energy 39, 7627-7633.

Dai, H., Xie, X., Xie, Y., Liu, J., Masui, T., 2016. Green growth: the economic impacts of large-scale renewable energy development in China. Appl. Energy 162, 435-449.

Davis, J.S., Peters, P.G., Calderia, K., 2011. The supply chain of $\mathrm{CO}_{2}$ emissions. Proc. Natl. Acad. Sci. U. S A. 108, 18554-18559.

Deng, G., Ding, Y., Ren, S., 2016. The study on the air pollutants embodied in goods for consumption and trade in China-Accounting and structural decomposition analysis. J. Clean. Prod. 135, 332-341.

Duan, C., Chen, B., Feng, K., Liu, Z., Hayat, T., Alsaedi, A., Ahmad, B., 2018. Applied Energy. https://doi.org/10.1016/j.apenergy.2018.01.028.

Emissions Database for Global Atmospheric Research (EDGAR), 2016. $\mathrm{CO}_{2}$ Time Series 1990-2015 Per Region/Country Emissions. http://edgar.jrc.ec.europa.eu.

Fang, D., Chen, B., Hayat, T., Alsaedi, A., 2017. Emergy evaluation for a low-carbon industrial park. J. Clean. Prod. 163, S392-S400. 
Feng, K., 2012. Outsourcing $\mathrm{CO}_{2}$ within China. Proc. Natl. Acad. Sci. U. S. A. 110, 11654-11659.

Guevara, Z., Rodrigues, F.D.J., 2016. Structural transition and energy use: a decomposition analysis of Portugal 1995-2010. Econ. Syst. Res. 28, 202-223.

Guo, J., Zhang, Z., Meng, L., 2012. China's provincial $\mathrm{CO}_{2}$ emissions embodied in international and interprovincial trade. Energy Pol. 42, 486-497.

Hienuki, S., Kudoh, Y., Hondo, H., 2015. Establishing a framework for evaluating environmental and socio-economic impacts by power generation technology using an input-output table-A case study of Japanese future electricity grid mix. Sustainability 7, 15794-15811.

Horschig, T., Thrän, D., 2017. Are decisions well supported for the energy transition? A review on modeling approaches for renewable energy policy evaluation. Energy, Sustain. Soc. 7 (5). https://doi.org/10.1186/s13705-017-0107-2.

Hua, Y., Oliphant, M., Hu, J.E., 2016. Development of renewable energy in Australia and China: a comparison of policies and status. Renew. Energy 85, 1044-1051.

Jiang, Y., Cai, W., Wan, L., Wang, C., 2015. An index decomposition analysis of China's interregional embodied carbon flows. J. Clean. Prod. 88, 289-296.

Joshi, 1999. Product environmental Life-Cycle Assessment using input-output techniques. Ind. Ecol. 3, 95-120.

Kosuke, K., 2003. Energy from the Desert: Feasibility of Very Large Scale Photovoltaic Power Generation (LVS-pv) Systems. James \& James (Science Publishers), London.

Kumar, I., Tyner, W.E., Sinha, K.C., 2016. Input-output life cycle environmenta assessment of greenhouse gas emissions from utility scale wind energy in the United States. Energy Pol. 89, 294-301.

Lahr and de Mesnard, 2004. Biproportional techniques in input-output analysis: table updating and structural analysis. Econ. Syst. Res. 16, 115-134.

Lee, D., Lee, D., Chiu, L., 2011. Biohydrogen development in United States and in China: an input-output model study. Hydrogen Energy 36, 14238-14244.

Li, Y., Hewitt, C.N., 2008. The effect of trade between China and the UK on nationa and global carbon dioxide emissions. Energy Pol. 36, 1907-1914.

Li, X., Feng, K., Siu, L.Y., Hubacek, K., 2012. Energy-water nexus of wind power in China: the balancing act between $\mathrm{CO}_{2}$ emissions and water consumption. Energy Pol. 45, 440-448.

Li, Y., Lukszo, Z., Weijnen, M., 2016. The impact of inter-regional transmission and gird expansion on China's power sector decarbonization. Appl. Energy 183, $853-873$.

Lin, J., Pan, D., Davis, S.J., Zhang, Q., He, K., Wang, C., Streets, D.G., Wuebbles, D.J., Guan, D., 2014. China's international trade and air pollution in the United States. Proc. Natl. Acad. Sci. U. S. A. 111, 1736-1741.

Liu, Z., 2015. China's Carbon Emissions Report 2015. Sustainability Science Program and Energy Technology Innovation Policy Research Group, Belfer Center Discussion Paper. Harvard Kennedy School of Government, Cambridge, MA.

Liu, W., Chen, J., Tang, Z., Liu, H., Han, D., Li, F., 2012. China's 30 Provincial Multiregional Input-output Table Theory and Practice in 2007. China Statistics Press, Beijing (in Chinese).

Liu, W., Tang, Z., Chen, J., Yang, B., 2014. China's 30 Provincial Multi-regional Inputoutput Table Theory and Practice in 2010. China Statistics Press, Beijing (in Chinese).

Liu, H., Liu, W., Fan, X., Zou, W., 2015a. Carbon emissions embodied in demandsupply chains in China. Energy Econ. 50, 294-305.

Liu, Z., Davis, S.J., Feng, K.H., Hubacek, K., Liang, S., Anadon, D.L., Chen, B., Liu, J.R., Yan, J.Y., Guan, D.B., 2015b. Targeted opportunities to address the climate-trade dilemma in China. Nat. Clim. Change 6, 201-206.

Liu, X., Klemes, J.J., Varbanov, S.P., Cucek, L., Qian, Y., 2016a. Virtual carbon and water flows embodied in international trade: a review on consumption-based analysis. J. Clean. Prod. 146, 22-28.

Liu, Y., Meng, B., Hubacek, K. Xue, J., Feng, K., Gao, Y., 2016b. Made in China": reevaluation of embodied $\mathrm{CO}_{2}$ emissions in Chinese exports using firm heterogeneity information. Appl. Energy 184, 1106-1113.

Liu, Y., Chen, S., Chen, B., Yang, W., 2017. Analysis of $\mathrm{CO}_{2}$ emissions embodied in China's bilateral trade: a non-competitive import input-output approach. J. Clean. Prod. 163, 410-419.

Meng, B., Xue, J., Feng, K., Guan, D., Fu, X., 2013. China's inter-regional spillover of carbon emissions and domestic supply chains. Energy Pol. 61, 1305-1321.

Mi, Z., Meng, J., Guan, D., Shan, Y., Song, M., Wei, Y.-M., Liu, Z., Hubacek, K., 2017. Chinese $\mathrm{CO}_{2}$ emission flows have reversed since the global financial crisis. Nat. Commun. 8, 1712. https://doi.org/10.1038/s41467-017-01820-w.

Miller, R.E., Blair, P.D., 2009. Input-output Analysis: Foundations and Extensions, second ed. Cambridge University Press, Cambridge, UK.

Nagashima, S., Uchiyama, Y., Okajima, K., 2017. Hybrid input-output table method for socioeconomic and environmental assessment of a wind power generation system. Appl. Energy 185, 1067-1075.

National Bureau of Statistics of China (NBS), 2003. 2002 China Energy Statistica Yearbook. Chinese Statistics Press, Beijing (in Chinese).

National Bureau of Statistics of China (NBS), 2008. 2007 China Energy Statistical Yearbook. Chinese Statistics Press, Beijing (in Chinese).

National Bureau of Statistics of China (NBS), 2011. 2010 China Energy Statistical Yearbook. Chinese Statistics Press, Beijing (in Chinese).

National Bureau of Statistics of China (NBS), 2015a. 2014 China Energy Statistical Yearbook. Chinese Statistics Press, Beijing (in Chinese).

National Bureau of Statistics of China (NBS), 2015b. 2014 China Statistical Yearbook. Chinese Statistics Press, Beijing (in Chinese)

Peters, G.P., Minx, J.C., Weber, C.L., Edenhofer, O., 2011. Growth in emission transfers via international trade from 1990 to 2008. Proc. Natl. Acad. Sci. U. S. A. 108
$8903-8908$

Qi, T., Winchester, N., Karplus, V.J., Zhang, X., 2014a. Will economic restructuring in China reduce trade-embodied CO2 emissions? Energy Econ. 42, 204-212.

Qi, T., Zhang, X., Karplus, J.V., 2014b. The energy and $\mathrm{CO}_{2}$ emissions impact of renewable energy development in China. Energy Pol. 68, 60-69.

Rodrigues, J.F.D., 2014. A Bayesian approach to the balancing of statistical economic data. Entropy 16, 1243-1271.

Rodrigues, J.F.D., Lorena, A., Costa, I.S., Ferrão, P., 2016. An input-output model of extended producer responsibility. J. Ind. Ecol. 20, 1273-1283.

Shi, M.J., Zhang, Z.Y., 2012. Multi-regional Input-output Model and Inter-regional Economic Linkages. Science Publishing House, Beijing (in Chinese).

Song, J., Yang, W., Higano, Y., Wang, X., 2015a. Introducing renewable energy and industrial restructuring to reduce GHG emission: application of a dynamic simulation model. Energy Convers. Manag. 96, 625-636.

Song, J., Yang, W., Higano, Y., Wang, X., 2015b. Modeling the development and utilization of bioenergy and exploring the environmental economic benefits. Energy Convers. Manag. 103, 836-846.

Sonnenschein, J., Mundaca, L., 2016. Decarbonization under green growth strategies? The case of South Korea. J. Clean. Prod. 123, 180-193.

State Grid of China (SGC), 2008. Annual Report of Power Market Transactions 2007. China Electricity Council, Beijing (in Chinese).

State Grid of China (SGC), 2011. Annual Report of Power Market Transactions 2010. China Electricity Council, Beijing (in Chinese).

State Grid of China (SGC), 2015. Annual Report of Power Market Transactions 2014 China Electricity Council, Beijing (in Chinese).

Stromman, A.H., Hertwich, E.G., Duchin, F., 2009. Shifting trade patterns as a means of reducing global carbon dioxide emissions. J. Ind. Ecol. 13, 38-57.

$\mathrm{Su}, \mathrm{B} .$, Ang, B.W., 2010. Input-output analysis of $\mathrm{CO}_{2}$ emissions embodied in trade: the effects of spatial aggregation. Ecol. Econ. 70, 10-18.

Tang, Z., Liu, W., Gong, P., 2015. The measurement of the spatial effects of Chinese regional carbon emissions caused by exports. J. Geogr. Sci. 25, 1328-1342.

Tang, X., Jin, Y., Wang, X., Wang, J., Mclellan, B.C., 2017. Will China's trade restructuring reduce $\mathrm{CO}_{2}$ emissions embodied in international exports? J. Clean. Prod. $161,1094-1103$

The World Bank, 2013. China 2030: Building a Modern, Harmonious, and Creative High-income Society. http://worldbank.org/content/dam/Worldbank/ document/China-2030-complete.pdf.

Tian, P., Lin, B., 2017. Promoting green productivity growth for China's industrial exports: evidence from a hybrid input-output model. Energy Pol. 111, 394-402.

Tukker, A., Bulavskaya, T., Giljum, S., Koning, A de, Lutter, S., Simas, M., Stadler, K., Wood, R., 2014. The Global Resouces Footprint of Nations: Carbon, Water, Land and Materials Embodied in Trade and Final Consumption with EXIOBASE 2.1. The Netherlands Organization for Applied Scientific Research, Delft.

Varela-Vázquez, P., Sánchez-Carreira, M.D., 2015. Socioeconomic impact of wind energy on peripheral regions. Renew. Sustain. Energy Rev. 50, 982-990.

Vetőné Mózner, Z., 2013. A consumption-based approach to carbon emission accounting-sectoral differences and environmental benefits. J. Clean. Prod. 42, 83-95.

Wang, H., Zhang, Y., Lu, X., Nielsen, P.C., Bi, J., 2015. Understanding China's carbon dioxide emissions from both production and consumption perspectives. Renew. Sustain. Energy Rev. 52, 189-200.

Wang, H., Zheng, S., Zhang, Y., Zhang, K., 2016. Analysis of the policy effects of downstream Feed-in Tariff on China's solar photovoltaic industry. Energy Pol. 95, 479-488.

Wang, Y., Liu, H., Mao, G., Zuo, J., Ma, J., 2017. Inter-regional and sectoral linkage analysis of air pollution in Beijing-Tianjin-Hebei (Jing-Jin-Ji) urban agglomeration of China. J. Clean. Prod. 165, 1436-1444.

Weber, L.C., Peters, P.G., Guan, D., Hubacek, K., 2008. The contribution of Chinese exports to climate change. Energy Pol. 36, 3572-3577.

Weitzela, M., Ma, T., 2014. Emissions embodied in Chinese exports taking into account the special export structure of China. Energy Econ. 45, 45-52.

Wolfram, P., Wiedmann, T., Diesendorf, M., 2016. Carbon footprint scenarios for renewable electricity in Australia. J. Clean. Prod. 124, 236-245.

World Trade Organization, 2016. World Trade Statistical Review 2016. https://www. wto.org/english/res_e/statis_e/wts2016_e/wts2016_e.pdf.

Wu, J., Albrecht, J., Fan, Y., Xia, Y., 2016a. The design of renewable support schemes and $\mathrm{CO}_{2}$ emissions in China. Energy Pol. 99, 4-11.

Wu, R., Geng, Y., Dong, H., Fujita, T., Tian, X., 2016b. Changes of $\mathrm{CO}_{2}$ emissions embodied in China-Japan trade: drivers and implications. J. Clean. Prod. 112, $4151-4158$.

Xu, X., Mu, M., Wang, Q., 2017. Recalculating $\mathrm{CO}_{2}$ emissions from the perspective of value-added trade: an input-output analysis of China's trade data. Energy Pol. 107, 158-166.

Yushchenko, A., Patel, M.K., 2016. Contributing to a green energy economy? A macroeconomic analysis of an energy efficiency program operated by a Swiss utility. Appl. Energy 179, 1304-1320.

Zhang, Y., Tang, Z., 2015. Driving factors of carbon embodied in China's provincial exports. Energy Econ. 51, 445-454.

Zhang, B., Qiao, H., Chen, Z.M., Chen, B., 2015. Growth in embodied energy transfers via China's domestic trade: evidence from multi-regional input-output analysis. Appl. Energy 184, 1093-1105.

Zhang, C., Zhong, L., Liang, S., Sanders, T.K., Wang, J., Xu, M., 2017. Virtual scarce water embodied in inter-provincial electricity transmission in China. Appl. Energy 187, 438-448.

Zhao, Y., Wang, S., Zhang, Z., Liu, Y., Ahmad, A., 2016. Driving factors of carbon 
emissions embodied in China-US trade: a structural decomposition analysis. J. Clean. Prod. 131, 678-689.

Zhao, Y., Liu, Y., Zhang, Z., Wang, S., Li, H., Ahmad, A., 2017a. CO $_{2}$ emissions per value added in exports of China: a comparison with USA based on generalized logarithmic mean Divisia index decomposition. J. Clean. Prod. 144, 287-298.

Zhao, Y., Wang, S., Liu, Y., Zhang, Z., Zhang, Y., Li, H., 2017b. Identifying the economic and environmental impacts of China's trade in intermediates within the AsiaPacific region. J. Clean. Prod. 149, 164-179.
Zhao, Y.H., Zhang, Q., Guan, D.B., Davis, J.S., Liu, Z., Huo, H., Lin, T.J., Liu, D.W., He, B.K., 2015. Assessment of China's virtual air pollution transport embodied in trade by using a consumption-based emission inventory. Atmos. Chem. Phys. $15,5443-5456$.

Zhong, Z., He, L., Wang, Z., 2017. Geographic sources and the structural decomposition of emissions embodied in trade by Chinese megacities: the case of Beijing, Tianjin, Shanghai, and Chongqing. J. Clean. Prod. 158, 59-72. 